Portland State University

PDXScholar

6-15-2020

\title{
Christine de Pizan's Passive Heroines: Recoding Feminine Identities in Le Livre de la cité des dames and Le Ditié de Jehanne d'Arc
}

Evelyn Ives Mills

Portland State University

Follow this and additional works at: https://pdxscholar.library.pdx.edu/open_access_etds

Part of the Feminist, Gender, and Sexuality Studies Commons, French and Francophone Language and Literature Commons, and the Medieval History Commons

Let us know how access to this document benefits you.

\section{Recommended Citation}

Mills, Evelyn Ives, "Christine de Pizan's Passive Heroines: Recoding Feminine Identities in Le Livre de la cité des dames and Le Ditié de Jehanne d'Arc" (2020). Dissertations and Theses. Paper 5552.

https://doi.org/10.15760/etd.7426

This Thesis is brought to you for free and open access. It has been accepted for inclusion in Dissertations and Theses by an authorized administrator of PDXScholar. Please contact us if we can make this document more accessible: pdxscholar@pdx.edu. 
Christine de Pizan's Passive Heroines: Recoding Feminine Identities in Le Livre de la cité des dames and Le Ditié de Jehanne d'Arc

by

Evelyn Ives Mills

A thesis submitted in partial fulfillment of the requirements for the degree of

\author{
Master of Arts \\ in \\ French
}

Thesis Committee:

Gina Greco, Chair

Jennifer Perlmutter

Annabelle Dolidon

Portland State University

2020 
(C) 2020 Evelyn Ives Mills 


\begin{abstract}
Over the course of the twentieth and twenty-first centuries, Christine de Pizan has resurfaced in the academic and literary spheres as a paragon of proto-feminist thought. This modern fascination with the fifteenth-century writer is largely grounded in her surprisingly progressive views on a woman's right to receive an education, to govern and achieve financial freedom. More recently, scholars have lauded Christine's later works for their reinterpretation of what it meant to be a woman in fifteenth-century Europe. The present study examines this latter goal of Christine de Pizan's writing specifically in the context of the heroic feminine identity she constructs throughout Le Livre de la cité des dames and reiterates in her final work Le Ditié de Jehanne d'Arc. While Christine de Pizan's heroines have previously been the focus of many historians' and literary scholars' analyses, this investigation proposes a new interpretation of these women that examines the author's pointed use of language, religious symbolism and descriptions of the female body to construct a unique heroic identity - a synthesis of passivity, activity, the masculine and the feminine. Such an understanding of Christine's heroines also reveals the author's personal connection to the dynamic image of womanhood presented in her work, which in turn has implications for the historical practicality of Christine's passive heroines.
\end{abstract}


Acknowledgments

I would like to express my deepest gratitude to my advisor, Dr. Gina Greco, for allowing me to explore my research interests this year and whose unwavering support and guidance motivated me and kept me on track throughout this process. I would also like to thank my committee members, Dr. Jennifer Perlmutter and Dr. Annabelle Dolidon, for their insightful questions and suggestions during my defense, which helped to make my thesis a more complete work and have given me much to think about for future research projects. I could not have asked for a more positive experience. Lastly, I would like to express my appreciation to the entire French department at PSU, for fostering the kind of academic environment that encourages and supports its students' curiosity and independent work. 


\section{Table of Contents}

Abstract................................................................ i

Acknowledgments............................................................. ii

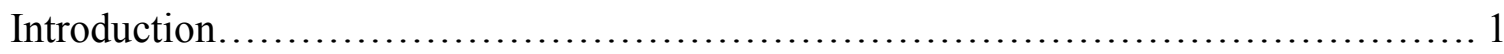

Chapter I

Reinterpreting Passive and Active Roles through Christine de Pizan's Atypical

Women................................................................... 11

Chapter II

Religious Subordination: Do Christine's Christian Heroines Own their Actions?.......... 38

Chapter III

Reimagining Feminine Identities: Between Practice and Literature................... 64

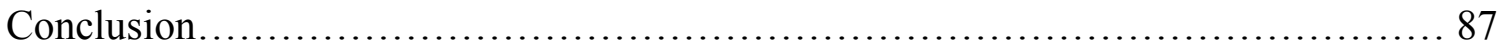

Works Cited......................................................... 93 


\section{Introduction}

By the time Christine de Pizan completed Le Livre de la cité des dames in 1405, the Italian born writer was already deeply embroiled in an argument between protofeminists and their male erudite contemporaries that would become known as the Querelle des femmes - a quarrel over the value of female influence in social, intellectual and political spheres that stretched on far into the seventeenth century. In fact, Christine herself is widely believed to have sparked the debate through her impassioned response to Jean de Meun's debasing sexualization and objectification of women in Le Roman de la rose (Adams 394). Although the work is fictional, Christine strongly believed that $\mathrm{Le}$ Roman de la rose was responsible for perpetuating the mistreatment of women in both literature and society. Her argument was grounded in the fifteenth-century concept of mos actisans, as Helen Solterer explains: "Coined by the philosopher-translator Nicole Oresme, and adapted in the Querelle by Christine de Pizan, this expression designates a kind of speech that possesses the force of deeds" ("Flaming Words" 357). So, for Christine, the verbal abuse and defamation of women in literature was tantamount to a very real and direct assault on women; and her solution was to counter Jean de Meun with her own enflamed and scathing mos actisans in the Epistre au dieu d'Amours, composed in 1399. Her battle did not stop there, however, and Christine turned her focus to responding to still other male writers whom she viewed as contributing to the rampant misrepresentation of women in literature, thereby upholding society's unjust treatment of nearly half of the population. 
Out of this fiery debate was born the Cité, a work that, at the surface, does not present itself as an overtly political or polemic piece, nor does it serve as a direct rebuttal to the texts, primarily those of Giovanni Boccaccio, ${ }^{1}$ that function at once as the Cité's model and point of departure. Nevertheless, the text's position is clear: to rectify the representation of women in literature and to demonstrate, beyond the shadow of a doubt, their validity as contributors to humanity's discoveries, triumphs of military and political power, and social order.

Broken into three Parts, the Cité chronicles the construction of a feminist utopian city narrated by a fictional Christine, aided by three allegorical figures, Ladies Reason, Justice and Rectitude who visit her as she laments one night at the depravity of her sex. Each Part of the Cité constitutes a separate step in the construction of this fictional utopian city: Part I contains the tales of legendary and mythical military and innovative women who serve as the city's foundations and walls. Part II recounts the lives of prophetic women and the many noble, brave and loyal women who make up the city's internal protection and are the first to populate its homes. Part III is reserved for the most illustrious inhabitants of the city's palaces - the virgin martyrs. Although the utopian city that Christine, Reason, Justice and Rectitude build is fictional, each chapter of the book serves a very real purpose: to disprove a stereotype of the female sex and to assert the validity of feminine authority. In the final pages, Christine-protagonist turns her

\footnotetext{
${ }^{1}$ For thorough analyses and discussions of Christine's use of Boccaccio in Le Livre de la cité des dames and other works, see Kevin Brownlee's chapter "Christine Transforms Boccaccio: Gendered Authorship in the De mulierbus claris and the Cité des dames" in Reconsidering Boccaccio: Medieval Contexts and Global Intertexts as well as his article "Christine de Pizan's Canonical Authors: The Special Case of Boccaccio" (244-61, 246-59).
} 
discourse outward in a resounding call to arms. The narrator implores all women, past, present and future, of all social status and position, to heed her warnings against the manipulation of the misogynistic tradition and to uphold and continue the work of the Cité.

Twenty-five years after Christine penned the Cité and called for her female audience to carry on the fight against the misogynistic practices of European society, a young woman presented herself to the French court as sent from God to help bring France to victory against the British and restore the French monarchy under Charles VII. This woman was of course, Joan of Arc. Cloistered in the Abbey at Poissey, Christine de Pizan heard of Joan's arrival and immediately believed her to be the fulfillment of multiple popular prophecies concerning a divine French savior (Arden 197-8). The author, who had long retired from public life, was so inspired, and, it seems, felt such a strong connection to Joan, ${ }^{2}$ that she took up her pen once more in 1429 to compose Le Ditie de Jehanne d'Arc, a poem intended to defend the mission of the Maid of Orléans that simultaneously proved the arguments made in Christine's Cité through a very real and contemporary heroine. Alan P. Barr notes just how serendipitous Joan's arrival was for Christine's life-long work: “The advent of La Pucelle was almost inconceivably opportune - as symbol as well as substantial reality...With little manipulation of the current reality, Joan is transformed into the most illustrious figure in a tradition that depended upon example" (4-5).

${ }^{2}$ For a complete discussion of Christine de Pizan's perceived personal connection to Joan of Arc, see Heather M. Arden's chapter in Joan of Arc and Spirituality, "Christine de Pizan's Ditié de Jehanne d'Arc: History, Feminism, and God's Grace” (195-208). 
While there are multiple points of connection between Christine's Joan of Arc and the illustrious women of the Cité, each equally deserving of investigation, I am particularly interested in how Christine de Pizan constructs the unique heroic identities of Joan, in addition to many of the women who populate her fictional city. As I stated earlier, the intent of Christine's mos actisans in the Cité was to validate feminine authority through a powerful literary genealogy of women, historical and mythical, who challenged the era's belief that women were intrinsically inferior, depraved and prone to sin. Men were perceived to be naturally rational and thus worthy of greater agency and authority, while women were naturally sensitive, irrational and unpredictable - their activity was regarded as threatening to the rationality of men (Robertson 144-9). To disprove and counter these assumptions, which Christine believed to hold little truth, and merely served to oppress women and uphold an unjust hierarchy of genders, many of the Cité's heroines take on distinctly masculine - active - roles and even appearances to demonstrate women's equal, if not superior, capabilities in roles of action and authority such as governing and warfare. Joan of Arc clearly shares this particularity as a young woman who leads France's army into battle, dressed in armor and having cut her hair - a significant symbol of femininity. Despite their masculine behavior and/or appearances, Christine de Pizan continuously emphasizes the femininity of the women of the Cité, as well as that of Joan of Arc. Their womanliness is central to the atypical roles they take on. Whereas the inversion of gender roles can be expected of any feminist text, and in this case, a proto-feminist text, it is decidedly less common to employ and highlight the very characteristics and roles otherwise used in the subjugation and objectification of 
women, as fundamental to their active, rebellious identity; and yet, this is precisely what Christine de Pizan accomplishes in both the Cité and the Ditié.

Thus, it is this unique interpretation of feminine roles and heroic identities that will be the subject of the present study. Over the course of the discussion and analyses that follow I will demonstrate that Christine's heroines can be characterized by their synthesis of passivity and activity - an identity their author constructs through her careful use of language, descriptions of the female body, as well as religious symbolism. In addition, I will argue that Christine de Pizan recodes these feminine roles, both typical and atypical, to create a space for and validate the existence of dynamic and complex women, not only in literary history, but also in her immediate reality.

I will foreground my investigation in a comparison of Christine's heroines to late medieval popular and medical beliefs about gender roles and the gendered body, in addition to medieval hagiographical representations of gender - women and the female body in particular. In Chapter I, I will define concepts of passivity and activity as they pertain to my thesis and within the context of the Cité and the Ditié. However, the primary focus will be to address the following questions: what role do gender and the body play in Christine de Pizan's depiction of active and passive roles? How does she reinterpret typically feminine attributes and subordinate positions to reflect authority? I will frame my responses to these questions in the examples of Joan of Arc and several women depicted in the Cité: Queens Zenobia and Hypsicratea, Minerva, the Sabines, and an unnamed woman who nurses her mother in prison. Each of these women provides insight into Christine's strategic use of passivity and activity in a slightly different way, 
therefore Chapter I will be divided into three subcategories: The Female Body as Masculine; Naivety, Weakness, Virginity and Chastity as Power; and The Maternal Body as an Instrument of War and Rebellion.

Chapter II will address the effect of religion on the construction of Christine's heroic identity, uniquely as it pertains to the author's distinctly Christian heroines - Joan of Arc, Saint Catherine and Saint Christine. I have chosen to separate Joan and Saints Catherine and Christine in this chapter, owing to the fact that at the time of the Ditie's composition, Joan of Arc was not officially recognized as a saint. While she is certainly a Christian heroine, virgin martyrs and saints held a different significance in literature that requires a separate examination. I will argue that first and foremost, the subordination of heroes under God is not limited to women, as has been previously suggested. ${ }^{3}$ Instead, when we examine Christine's treatment of Christian heroes and heroines in the context of her contemporary Giovanni Boccaccio's work The Fates of Illustrious Men (De casibus virorum illustrium), it becomes clear that these figures are necessarily passive, but that at the same time, a distinction should be made between their figurative authority and grammatical subordination. Secondly, I will demonstrate that Christine de Pizan uses both the symbolism of the holy maiden as well as pagan associations of maidenhood with sexuality and desirability to elevate the authority of her virgin martyrs.

My third and final Chapter will broaden the discussion to examine the origins of Christine's passive heroines and the implications of this identity in historical practice. I will contend that when we examine the Cité in the context of Christine de Pizan's own

\footnotetext{
${ }^{3}$ Kevin Brownlee contends that female Christian heroism is "fundamentally passive" ("Structures of Authority" 132).
} 
upbringing and major life events, it becomes clear that the dynamic identities of Christine's heroines represent a synthesis of the passive, the active and often the masculine and the feminine, and reflect the author's own complex identity that she struggled with well into her adulthood. This connection to Christine de Pizan's personal experience as a woman helps to ground her fictional and mythical heroines in historical reality. Furthermore, I will argue that when we examine historical figures both directly and indirectly linked to Christine de Pizan's texts and who intrinsically reflect a similar complex and multifaceted identity deemed inappropriate and/or atypical by society, the significance of Christine's attempt to validate and recode feminine roles and identities becomes all the more significant.

Before continuing on to my analyses of the two texts, I feel it is necessary to discuss some of the previous research surrounding the topics at hand in both the Cite and the Ditié that has inspired and informed my investigation. While I do not agree entirely with each of the following scholars' studies, they have provided an invaluable foundation on which I built my own analysis, and provided significant insight into Christine de Pizan's skilled use of language and allegories in her writing.

Due to the rarity of medieval women being depicted as dynamically as Christine de Pizan does in the Cité, the text and its atypical women have been studied in depth. Maureen Quilligan contends that Christine's unique women reflect the author's intent to reclaim female authority through historical and literary depictions of women and to redefine the female experience ("Rewriting the Body" 219). Laura Renaldi Dufresne echoes a similar sentiment, pointing to Christine's devotion of much of Part I of the Cité 
to the Amazon warriors, whom the author views as exempla of female strength and virtue even in their self-mutilation - the Amazon women cut off their warriors' left breasts for ease in battle - an act that earned them significant criticism from male writers in previous accounts (121). The mutilated or transformed female body, is, in fact common imagery in the Cité as both authors observe, suggesting that Christine uses the body deliberately in this manner to reclaim agency, and as a metonymy for the female authorial voice.

Moreover, author Kevin Brownlee has demonstrated in detail how Christine's redefinition of the female experience extends into the very language she utilizes. Notably, Brownlee has studied the Cité in the context of Giovanni Boccaccio's works, De mulierbus claris and the Decameron, noting the implications of their differences as well as similarities ("Christine Transforms Boccaccio" 247). Brownlee contends that the goal of Christine's use of Boccaccio's works is twofold: "the valorization of women simultaneously involves the valorization of Christine de Pizan as author..." ("Christine de Pizan's Canonical Authors” 256). In establishing not only her gender's authority and merit, but also her own, Christine ensures the continuation of the female voice by embodying it.

While scholars tend to agree regarding the objectives of the Cité, the same cannot be said about the Ditié. Research appears to be divided into two camps either examining the political importance of the poem or its significance as a proto-feminist piece. The latter studies discuss Joan's heroism as a female military leader and the effect her advent had on the socio-political and cultural atmospheres of the time. As Nancy Bradley Warren aptly observes: "Joan of Arc, cross-dressing virgin and at least temporarily 
successful military leader...provoked a 'fear that the powerful body of the English...was being unmanned"' (410). The seemingly miraculous albeit unusual nature of Joan is further underscored by her frequent connection to prophecy. Maureen Quilligan traces the line of Christine de Pizan's focus on sibylline prophecy from one of her earliest texts, Epistre Othéa through the Cité, ending at the Ditié. In fact, Quilligan observes that Christine uses prophecy to justify Joan's arrival, and to herself become a prophetess of sorts, predicting Joan's continued victories ("The Practice of History" 278-80).

Countering the feminist interpretation of the Ditié, several researchers have highlighted portions of the poem that express fervent disdain for the English. Nowacka contends that: "its anti-English diatribe and exaltation of France suggests that it was intended to inspire patriotic fervor" (87). Rosalind Brown-Grant agrees; in her examination of heroism in the Ditié, she observes that while many readers associate Christine de Pizan with her later proto-feminist works, many of her earlier texts were political in nature. Brown-Grant proposes that Christine's political history is the main influence behind the Ditié and even "dictated the terms in which Christine chose to depict her heroine" (128). Furthermore, while he does not agree entirely with the contention that the Ditié 's intent was, first and foremost, political, Kevin Brownlee does concede that Joan of Arc's subordination under God diminishes her status as a woman warrior, perhaps to serve the political tone of the piece, noting the significance of Charles VII as the poem's primary subject ("Structures of Authority"132). From this perspective, then, the Ditié's celebration of women is secondary to its political agenda. 
The existing research on Christine de Pizan, Le Livre de la cité des dames and Le Ditié de Jehanne d'Arc provides insightful and detailed analyses of the themes, motifs, language and influences of the works. Authors such as Brownlee, Brown-Grant and Quilligan have paved the way into the examination of Christine's heroines and have built the foundation for studying gender and authority in Christine and her contemporaries' texts. While these scholars' conclusions and those of their peers are essential to the critical analysis of Christine's works, particularly the Cité and the Ditié, the existing research falls short of examining Christine de Pizan's synthesis of passivity and activity within her heroines, choosing instead to regard these concepts as distinctly separate or in opposition to one another. Consequently, the reader is sometimes left with conflicting opinions as to how, exactly, Christine's heroines should be received. I do not believe that in the context of Christine de Pizan's work, these concepts were intended to be incompatible or separate. Therefore, I would like to present a slightly different reading of the Cité and the Ditié, one that attempts to define the identities of Christine's heroines in their entireties. 


\section{Chapter I}

\section{Reinterpreting Passive and Active Roles through Christine de Pizan's Atypical}

\section{Women}

The concept of passive protagonists and heroines seems at first glance to be a glaring oxymoron. After all, our definitions of these literary roles are built upon a presumption of action. Examining Joan of Arc, Rosalind Brown-Grant outlines an albeit modern understanding of heroism using the criteria laid out by historian Marina Warner: ${ }^{4}$ "Joan is a heroine according to three main criteria: her potential status as a female role model, her independence of action, and her dynamism" (125). Central to this definition are independence and dynamism, suggesting that above all, an inner locus of control (the theory that the individual affects changes of the self and influences his/her environment through his/her personal agency), is the pillar of heroism. How, then, may a heroine or hero be passive? In my analyses of Christine de Pizan's atypical women, I will explore this very conundrum. However, before diving into this discussion I believe it necessary to define my terminology, specifically that of passivity and activity as they pertain to the present study.

To define these terms within the literary context in which they are being discussed, I will use excerpts from Part II of Le livre de la cité des dames concerning the Sabines. Taken by force to be the wives of the newly founded city of Rome, the Sabines

\footnotetext{
${ }^{4}$ Brown-Grant goes on to argue in this article that Warner's criteria do not fit Joan's heroism. She contends that Christine de Pizan presents Joan's heroism as dependent on the grace of God, concluding that the subordination of her heroine was necessary to her political goal: to convince the French to put their faith in Joan (133). I will be addressing this theory in the following chapter as part of my discussion of the relationship between religion and passive/active roles.
} 
(daughters of Sabin royalty), throw themselves in between the armies of their fathers and their husbands - their captors - preferring to sacrifice themselves and their children rather than see their families at war with one another. Over the course of their story, the Sabines evolve from passive figures to active ones, responsible for saving countless lives:

Romulus se saisit de la fille du roi, dont il était déjà fort épris. Chacun suivit son exemple et s'empara de celle qu'il voulait. Ils emportèrent de force les femmes sur leurs chevaux et s'enfuirent vers la ville, où ils renfermèrent sur eux les portes de la cité. Les pères et les parents restés au-dehors se lamentaient à grands cris, ainsi que les femmes qu'on avait enlevées contre leur gré, mais les pleurs n'y firent rien. Romulus épousa avec faste la femme qu'il avait ravie, et les autres firent de même. (La Cité 174)

In this instance, the women are passive; they take no part in the action of the story, save for their futile cries for help. Of greater interest to our discussion, however, is the language Christine de Pizan uses in this paragraph to subordinate the Sabines. Unlike Romulus and his men, Christine uses the passive voice exclusively to refer to the women in the story: they are enlevées and the woman that Romulus abducts is only described as having been ravie by her captor. In short, the women are defined by the actions that are inflicted upon them. Even when referring to their protestations, Christine decides to designate them as an afterthought to the central subject (the fathers and family members) of the verb lamantaient. Thus, passivity is defined not only by the Sabines' (lack of) role in their own story, but by the language Christine de Pizan chooses to write them with; they are grammatically and figuratively subordinated. Examining the end of this chapter, we see these same passive women become active:

Alors la reine défit ses cheveux et se déchaussa. Toutes les femmes suivrent son exemple. Celles qui avaient des nourrissons les prirent dans leurs bras pour les emmener avec elles; il y avait là une multitude 
d'enfants et de femmes enceintes. La reine se mit en tête de ce pitoyable cortège. Elles parvinrent au champ de bataille au moment même où on allait livrer l'assault. Elles se mirent alors entre les deux armées, de sorte qu'il fallait leur passer sur le corps pour se battre. La reine et toutes les autres femmes s'agenouillèrent, et se lamentèrent à haute voix: 'Très chers pères et parents, et vous, époux très aimés, par pitié, faites la paix! Car sinon nous préférons toutes périr ici sous les sabots de vos montures!' (175)

I would like to first note the way in which this excerpt and the previous one mirror each other. Where Romulus leads the kidnapping of the Sabines, his men following his example, the Queen of the Sabines -Romulus's wife - is the first to undo her hair, take off her shoes and move towards the line of battle, the remainder of the women falling into step. Christine exchanges the opening sentences of these excerpts nearly identically, thus representing the Queen and the Sabines as equal to Romulus and his men, at once justifying their importance to the story and rendering them active participants. Grammatically, the women become the central subjects to many of the verbs of the paragraph. Whereas previously every event in the story happened to them, Christine alters her language, allowing the Sabines to affect the progression of their story. As with passivity, activity is then at once grammatical and figurative.

There is, however, a second level to the terms passive and active as they pertain to the subject matter at hand. Certain gendered characteristics and behaviors can be attributed to passive and active roles to both strengthen or reduce the significance of said roles and to subvert traditional notions of the feminine and masculine. When reading Christine de Pizan's works, one notes her frequent use of several key feminine characteristics to describe and even valorize her heroines - virginity, physical beauty, virtue, innocence, loyalty (often to a male figure), and softness (referring to both the body 
and character). Typically, these characteristics are reserved for passive figures, particularly those that describe the female body. Returning to the example of the Sabines, it is the Princess's beauty that leads to her becoming the object of Romulus's desire and eventual abduction. "Parmi elles se trouvait la fille, fort belle et pleine de grâces, du roi des Sabins..." (La Cité 173). In this instance, Christine associates physical beauty and by extension the female body with passivity, a practice that was not uncommon in literature during her time. ${ }^{5}$

Conversely, when in the same tale Christine de Pizan alters her language to depict the Sabines as active, she utilizes characteristics that are at the very least ambiguous in gender if not closer to what would be considered masculine during the fifteenth century, drawing attention no longer to their grace or beauty, but to their courage (175). This vocabulary legitimizes their action and is a strategy Christine de Pizan, as well as her contemporaries, employ frequently to underline the strength and authority of protagonists and heroes. What differentiates Christine from her contemporaries, however, is her attribution of chivalric and male characteristics to her female protagonists as a means of validating their position. While the literary practice of ascribing masculine traits to warring or governing women is not unique to Christine's work, her tone and intentions are. $^{6}$ "A woman who undertook the role of warrior would be forced, in the words of Saxo

\footnotetext{
${ }^{5}$ It was widely understood that upon reaching puberty, women were defined by an excess of cold and wet humors that indicated peak sexual desirability as well as women's inferiority and feebleness in relation to men, who maintained warm and dry humors throughout their lives. This medical theory is believed to be an influence behind constructions of female characters in literature (Phillips 24).

${ }^{6}$ Although examples of chivalric women depicted in a more positive light do exist, Christine de Pizan appears to be one of the few writers who does do so without ulterior motive. Helen Solterer examines Li Tournoiement as dames and argues that this work and others ultimately serve to
} 
Grammaticus, to 'unsex' herself, to abandon her true womanly nature and act with 'virile ruthlessness"” (McLaughlin 195). In none of the texts addressed in my research does Christine de Pizan suggest that her heroines become less of women in taking on male characteristics. Rather, Christine appears to understand the significance of the traditional link between chivalry, the male body and heroism (activity), and uses it to her advantage without 'unsexing' her heroines.

A final note should be made regarding Christine's use of gendered characteristics to imply passivity and activity. While the writer frequently follows tradition in using male characteristics to validate the heroic exploits of the female characters and often equates the female body with passivity, she also reverses the connotations of feminine and masculine traits on several instances in the Cité as well as the Ditié. These reversals will be discussed in detail later in this chapter, however, I feel it is necessary to draw attention to this practice here as part of the contextualization of my terminology.

\section{The Female Body as Masculine}

The first set of examples that I would like to address are those in which Christine de Pizan alters the bodies of her heroines, rendering them masculine or equating them with the male body. Such examples commonly include acts of crossdressing to escape wrongful persecution, violation, or to participate in battle. In general, warfare and governing are also common themes within these narratives. As has previously been noted, instead of fully transforming these women into male and/or sexless figures as was more common amongst authors of the time, Christine de Pizan appropriates what today

reinforce gender normative roles and fetishize the women portrayed ("Figures of Female Militancy" 533-34). 
we understand as masculinity to empower women. Examining Minerva in the Cité, who will be the first woman discussed in this chapter, Eleni Stecopoulos and Karl D. Uitti highlight the differences between Boccaccio's and Christine's use of male traits to describe women: “To Boccaccio's description of Minerva's stature as a symbol of the wise man, Christine adds the symbolism of chivalry...to complete the restoration of their rightful - indeed, humanly essential - feminine power" (55). Christine's addition to Boccaccio's version of the tale is significant, as the excerpt below demonstrates.

In Part I of the Cité, Reason recounts the tale of Minerva, a Greek virgin lauded for her vital contributions to science and the art of warfare. Reason tells Christineprotagonist that upon Minerva's death, the Athenians erected a temple in which they placed a statue of this great women. A description of the statue follows:

Elle portait un heaume parce que le chevalier doit être fort, aguerri et résolu sur le champ de bataille, mais aussi parce que les projets du sage sont voilés de secret. Elle était vêtue d'une cotte de mailles, emblème de cette puissance qui est celle de l'état de chevalerie, mais qui signifiait encore que le sage est toujours armé contre les vicissitudes de la Fortune, en bien comme en mal. Elle tenait à la main une haste ou une lance très longue, parce que le chevalier doit être le fer de lance de la Justice, mais aussi parce que le sage envoie ses traits de loin. Il y avait suspendu à son cou une targe ou bouclier en cristal, parce que le chevalier doit toujours être sur ses gardes et veiller en tout à la défense de son pays et de son peuple, mais cela signifiait aussi qu'au sage, tout est clair et évident. (103)

As Stecopoulos and Uitti note, Christine adds to Minerva's status as a symbol of wisdom, that of chivalry to further represent her unique authority. Minerva is clothed in armor befitting a noble knight and carries symbols further representing her military prowess and wisdom. Thus, Christine's version of the tale places greater emphasis on the physical body; Minerva is not only intellectually masculine, but physically so as well. Of equal 
importance is Christine's use of gendered language. Three of the four sentences begin with the pronoun elle referring Minerva, or rather her likeness as it is depicted by the statue. However, in each of these sentences Christine refers to elle as le chevalier and le sage, effectively altering the gender of the object of her description. While partly a necessity of the French language, I believe this to be a deliberate choice of words on the part of Christine. Through her language, the writer combines the masculine and feminine body to justify Minerva's accomplishments. In the paragraphs preceding Reason's description of the statue, Minerva is praised equally for inventing armor and chariots as well as maintaining her virginity, which further suggests that Christine's choice of gendered language is strategic rather than coincidental:

A cause de cette chasteté exemplaire, les poètes racontèrent dans leurs fables que Vulcain, dieu du feu, s'était longuement affronté à elle, mais qu'à la fin elle le domina et triompha de lui, ce qui signifie qu'elle triompha des feux de la concupiscence charnelle, qui couvent particulièrement dans la jeunesse. (102)

In this instance, Christine depicts the preservation of virginity using a lexicon of waraffronté, domina, triompha. Minerva's fight for her virginity, a state of being intimately tied to her identity as a woman, is also tied to her chivalric accomplishments. Does Minerva's invention of armor serve as metaphoric protection against seduction and personal ruin? It seems likely that we are meant to draw this conclusion.

As in relation to her scientific and military inventions, Minerva is presented as active in relation to her own body - it is she alone who affects the progress of humanity as well as protects her virtue. The latter fact is particularly unique to the narrative. The concept of virginity during this late medieval era was closely bound to innocence and 
delicateness, notions that I have previously identified as frequently being representative of figurative passivity in female literary characters (Phillips 44). This does not appear to always be the case in Christine de Pizan's work; something Dufresne has also observed: "Chastity is valued by Christine not for its maidenly purity, but rather because it frees women from the domination of men..." (121). In fact, in the case of Minerva Christine de Pizan not only attributes her numerous successes to her preserved state of virginity but suggests that to do so requires a level of bravery and courage akin to that of knights entering battle. Thus, while Minerva does not evolve from passivity to activity grammatically as the Sabines do, Christine presents her virginity as a feat born of her contributions to humanity and representative of Minerva's authority as a symbol of chivalry and wisdom.

While Minerva is somewhat unique in that she remains the active subject throughout her story, Christine de Pizan often alternates between the passive and active in her narration - the story of the Sabines is but one example of this. Variation in gendered language is also particularly present in Part II of the Cité, in which Christine-protagonist learns of the tale of Queen Hypsicratea who, suspecting that her husband's soldiers and servants will betray him, disguises herself and follows him into battle. The scene in which Hypsicratea cross-dresses is particularly revelatory of how Christine de Pizan uses the body to render her subjects active:

Ne se souciant pas plus de la belle fraîcheur de son teint, elle revêtit le heaume, sous lequel elle était souvent sale, recouverte de sueur et de poussière. Elle fit encore plier son beau corps délicat sous le poids des armes et d'un haubergeon bardé de fer; elle ôta les anneaux précieux et les riches joyaux qui ornaient ses mains pour prendre la hache tranchante, la lance, l'arc et les flèches; en lieu et place de ses riches ceintures, elle 
ceignit enfin l'épée. Telle fut la force de son immense et loyal amour que le beau corps de cette noble dame - doux, jeune, svelte et fait pour la douceur - se transforma en celui d'un chevalier armé, fort et bien musclé. $(148-49)$

It is important to keep in mind whilst analyzing this passage that Hypsicratea is above all defined by the love she bears for her husband: "Aucun homme ne pourrait servir son époux aussi sûrement, aussi loyalement ou aussi fidèlement qu'elle même" (La Cité 148). Although it is worth noting that Christine classifies her loyalty and consistency as superior to that of any man, the Queen's identity is nonetheless presented as dependent on her relationship to her King. Hypsicratea is therefore in a subordinated (passive) position. Knowing this, I believe, renders the description of Hypsicratea's transformation all the more significant. The beauty and physicality of her body is emphasized throughout this passage, her body is fait pour la douceur, which in this instance implies she is made for passivity, for love and loyalty to her husband. Such a description objectifies Hypsicratea's body, stopping just short of sexualizing it. Yet, in the same sentence, her body becomes masculine. While Christine suggests in this passage (and reiterates several lines later while quoting Boccaccio) that it was her immense love that caused the Queen to alter her body, Hypsicratea nonetheless maintains a grammatically active role in relation to action of this scene. The Queen and her body remain interchangeably the subjects of the verbs that Christine employs. The writer could have chosen to use the passive voice to describe Hypsicratea's transformation, after all it is made clear that love is the driving force behind her actions, thus subordinating her once again; however, Christine chose to give her heroine agency over her body. Despite her passive position in relation to the power of love and her King, the Queen's actions are her own. 
Christine made a similar decision in writing the tale of Minerva. As I noted previously, Minerva's ability to preserve her virginity is presented as a feat equal to, if not more impressive than, her scientific and militaristic inventions. In fact, Christine de Pizan declares that it is so miraculous that poets write ballads about her triumph over temptation and passion (La Cité 102). Just as in the case of Hyspicratea, Christine gives agency to Minerva over her body. Why then, after restoring bodily authority to these women, does Christine make the authorial decision to depict these same bodies as masculine? In part, this practice seems to be a means of validation and justification of women's participation in war and military practices. Christine's appropriation of the masculine body can be interpreted as an extension of her use of her male contemporaries' works as models for the Cité. In his research on this topic, Kevin Brownlee suggests that Christine appropriates Boccaccio's writing to validate her own authorial position ("Christine de Pizan's Canonical Authors" 256). It is possible, then, to conclude that Christine's depiction of Minerva and Hypsicratea's bodies as masculine is intended to validate the agency she is according them.

We may also examine the appropriation of the male body in terms of Judith Butler's theory of performative gender. Butler postulates that "genders can be neither true nor false, neither real nor apparent, neither original nor derived" (475). Furthermore, she argues that gender is only created through repetition and performance (acting out a gender), thus the construct of gender is fluid, and, importantly, external, meaning corporal. For Butler, the body is merely a boundary between internal and external identities and can be altered to reflect either truth (474). We can apply the notion that 
gender is created through its performance to the examples of Minerva and Hypsicratea. In both examples, Christine does not intend to suggest that these women become men.

Rather she uses the male body to depict her heroines as active figures of authority and agency. In this sense, Minerva and Hypsicratea are performing gender - they are imitating the male body by altering their own temporarily, and to serve a distinct purpose.

\section{Naivety, Weakness, Virginity and Chastity as Power}

While Christine de Pizan frequently restores authority to her heroines through bodily transformation and gives them agency over their female bodies, the writer also chooses to subvert notions of female frailty (body, mind and character) establishing them as integral to her heroines' active identities. It is worth noting that in addition, Christine does not limit this practice to her female figures. In Part I of the Cité Reason and Christine-protagonist discuss whether the natural weakness of women makes them less worthy of praise or less capable of participating in society:

Je te promets, chère enfant, qu'un physique puissant et vigoureux ne fait pas l'âme courageuse et forte, car cela vient d'une force naturelle de caractère... On voit en effet que beaucoup d'hommes grands et forts sont lâches et veules, alors que d'autres, petits et faibles de corps, sont hardis et entreprenants. (67)

Reason insists that the body is not always representative of the strength and worth of a soul, even in men. Her presumption further suggests that Christine-author's use of the physical body as a performative tool is used to justify authority. In presenting first the possibility of weak men as powerful, Christine de Pizan is effectively preparing her audience to accept the possibility of weak women as powerful. As I have previously noted, in the story of Minerva, Christine elevates the preservation of virginity as an 
accomplishment equal to her invention of armor and military arms. In addition to giving Minerva agency over her body, Christine essentially presents Minerva's virginity as part of her decidedly active identity. While in the previous section I focused on Christine de Pizan's presentation of her heroines as masculine and/or as performing masculine roles and traits to both justify their active position in relation to their stories, as well as to give authority to an otherwise subjugated character, in this section I will address the instances in which Christine de Pizan aligns characteristics typically associated with female passivity and submission with an active and/or authoritative identity.

The first of such instances that I will examine is that of Joan of Arc as she is depicted in Christine de Pizan's poem Le Ditié de Jehanne d'Arc. In many ways, we may conclude that Joan is also performing gender as well - she dons armor, takes up arms and leads the French soldiers into battle; a role like Queen Hypsicratea in the Cité. However, I contend that in lieu of presenting Joan's body as masculine-like to justify her authority, Christine de Pizan instead justifies and strengthens the Maid's position through her perceived frailty as a young woman:

Car, se Dieu fist par Josué Des miracles à si grant somme, Conquerant lieux, et jus rué Y furent maint, il estoit homme Fort et puissant. Mais, toute somme, Une femme - simple bergiere Plus preux qu'onc homs ne fut à Romme! Quant à Dieu, c'est chose legiere. (lines 193-200)

In this stanza, Christine clearly highlights Joan's unremarkable identity - a simple shepherdess- as crucial to her accomplishments. In fact, Christine uses her heroine's simplicity to designate her as superior to Joshua through whom God also chose to carry 
out his mission. This stanza also bares similarities to the passage from the Cité I cited in the beginning of this section. Although Joshua was a strong and powerful man, Joan, according to Christine, is even more powerful, despite lacking the physical strength of her male counterparts. Thus, we see the lesson of Reason reiterated: strength of spirit can outweigh that of the body. However, I believe that Christine's depiction of Joan of Arc takes Lady Reason's lesson still further through her frequent repetition of her heroine's status as an innocent and inconsequential maiden. Kevin Brownlee suggests that the extraordinary circumstances of Joan's accomplishments are intrinsically linked to her identity as woman: "Because she is a woman, her achievement is by definition greater than that of her male Biblical models..." ("Structures of Authority" 136). Brownlee is drawing upon the notion which holds true today - for women to be equal to men they must be extraordinary. While I agree with his assessment, I posit that Christine's use of Joan's gender is even more complex.

Of interest is the writer's frequent use the diminutives pucellette and filletteterms more often used to denote passive female characters - to refer to Joan of Arc. Nadia Margolis's research regarding the significance of diminutives in Christine's as well as Jean de Meun's work offers several possible interpretations: 1) Echoing Kevin Brownlee, Margolis suggests that Christine's use of the diminutive pucellette indicates the miraculous nature of a seemingly impossible feat - that a woman could surpass men in battle, 2) that Christine intends to suggest that "we are all lesser creatures before God...” and 3) Christine de Pizan is using the vernacular to reposition herself and her heroines within the language of the common-folk, redefining the vernacular (113-14). I 
will address the second of these interpretations in the following chapter as part of my discussion of the place of religion in Christine de Pizan's heroines; however, for the purposes of the current discussion I would like to focus on the third of Margolis's conclusions - Christine is "rewriting" the vernacular. Margolis notes that in Christine's previous works she has aligned the diminutive with passivity: "The real-life figure of Joan...also informs the poet's discursive shift from the passive, vulnerable filete of the Dit de la Pastoure (line 419) to the active, though still pure fillete celebrated in the poet's last known work" (114). This observation is significant first and foremost because Margolis underscores Christine de Pizan's strategic use of a vernacular term which, typically used as pejorative and/or indicative of the passivity and weakness of its subject, the writer instead chooses to employ to describe an active and heroic figure, thus recontextualizing the common language. Secondly, Margolis notes the use of the diminutives fillete and pucellette in Christine's representation of Joan as indicating that the (active) heroine remains nonetheless pure (not only of body but presumably soul as well). Taking the latter observation a step further, I ask the question: does the Maid of Orléans remain pure despite her heroic acts which do not conform to her gendered identity, or, is it her purity and status as "la Pucelle sensible" that facilitate her achievements (Le Ditié, line 111)? Again, turning to Lady Reason's lesson in Part I of Le Livre de la cité des dames, I believe that we may assume that Reason, Justice and Rectitude reflect to a large extent the thoughts and principles of Christine-author, and as such, when Reason states that many who are weak of body possess strength and ability, it is reasonable to conclude that Christine de Pizan believed this to be true as well. 
Applying this same reasoning to Nadia Margolis's conclusion that Christine's use of diminutive nomenclature implies that Joan remains a simple bergiere despite her gender nonconforming behavior, I propose that the author intended instead to suggest that Joan's purity and innocence are requisite to her heroic identity.

This brings us once more to the question of passivity. As I stated in the opening of this chapter, while Christine de Pizan often employs male characteristics to reinforce the active roles of her female protagonists, she also aligns characteristics typically indicative of female passivity with an active identity. Joan of Arc is one such example. Interestingly, Christine never describes Joan as masculine and Joan never undergoes any physical transformation from which she gains agency and strength. On the contrary, the writer deliberately refers to Joan as the pucelle, fillete, and pucellette each time she lauds Joan's military prowess and even physical violence. "N'y a si forte / Resistance qui à l'assault / De la Pucelle ne soit morte" (lines 406-08). Unlike Hypsicratea, Christine does not attempt to distance Joan from the feminine characteristics and attributes that would otherwise risk undermining her active role. Christine appears to indicate that the Maid of Orléans does not need to become a different (read masculine) version of herself to embody her role as a warrior; her innocence and purity only add to her strength. As I previously noted, Kevin Brownlee sees Christine's constant reiteration of Joan's social inferiority as a means of rendering her achievements utterly miraculous in the eyes of her male subject (Charles VII). While this conclusion is just and there is evidence to support it, I contend that we may also interpret this as Christine's strategic recoding of feminine characteristics - part of a pattern within her life's work. 
This work is equally evident in the Le Livre de la cité des dames. In Part II, Christine-protagonist learns of the story of a woman who frees her mother from prison and even nourishes her mother with her own breastmilk (a scene which merits a separate analysis). For the purposes of our current discussion, I will focus on how the young woman manages to gain access to her mother in prison:

Sa fille, poussée par son immense amour filial et désespérée de cette condamnation, demanda aux gardiens la faveur de rendre visite à sa mère tous les jours qu'il lui resterait à vivre, afin de l'exhorter au courage. Bref, elle pleura et supplia tant et si bien les gardiens de la prison qu'ils la prirent en pitié et lui permirent de venir voir sa mère tous les jours. (143)

Although this woman (who remains unnamed) differs from the women we have examined thus far in that she does not fulfill a masculine or atypical role, she is, nonetheless, representative of Christine de Pizan's treatment of female weakness as power. In this excerpt, the young woman cries and pleads with the guards to allow her to visit her mother; she lowers herself to a position of both passivity and submission - she is at the mercy of her male authorities. We may interpret this scene as another instance of gender performance. The unnamed woman is displaying weakness and an inability to master her emotions, something the guards would have expected from a young desperate woman. However, as the story progresses we learn that she is anything but what she presents to the guards; she is resourceful and brave: "La fille lui rendait donc en sa vieillesse ce qu'elle lui avait pris en son enfance...on raconta le fait aux juges qui, pris de compassion, libérèrent la mère et la rendirent à sa fille" (La Cité 143). While this woman remains passive in relation to the guards, who permit her to visit her mother, and the judges, who free her mother from prison, Christine de Pizan once more presents her 
protagonist as active in relation to her body - she nurses her mother - and, in this case, her emotions as well - she deliberately displays vulnerability. Christine subordinates her protagonist in order to give her agency in the section that follows, ultimately presenting her perceived feminine weakness as a tool to her strength.

I believe that Nadia Margolis's conclusion that Christine de Pizan intended to rewrite the vernacular in the Ditié, is applicable to this story as well. However, rather than the vernacular, Christine appears to be recoding feminine tropes and characteristics traditionally used to subordinate female characters in literature. Just as the writer repeatedly and pointedly refers to Joan of Arc using the diminutive whilst underscoring her strength as a military woman, Christine emphasizes the desperation and lack of authority of this woman. In both cases, Christine recodes passive language to validate the strength of her heroines. Joan of Arc's naivety is an asset to her identity as a female warrior and the unnamed woman who nurses her mother in prison displays weakness and submission to carry out an act of great courage and strength.

A final point should be made in this examination of Christine de Pisan's recoding of passive language and characteristics about the role of virginity and chastity in the active identities of many of her heroines. While virginity and abstinence from sexual intercourse cannot be definitively categorized as passivity or passive traits, they are, nonetheless, closely aligned with the notion. Elizabeth Robertson explains medieval medical views on the female body, noting that women were understood to be dominated by the cold and moist humors:

This insufficiency of heat led commentators to argue that women existed in a condition of perpetual desire. Women were believed to be driven by 
their craving for the hottest, most complete being, that is, the male...Women, though colder and moister than men, were believed to feel a more burning desire than men; it was in fact thought to be insatiable, in part because, as Jacquart and Thomasset point out, women were thought to experience a "pleasure that was greater in quantity, but lesser in quality and intensity than men's." The insatiability of feminine desire, an idea that has its roots in medical theory, permeated medieval thought and literature and reinforced male fear of female sexuality. (147)

Thus, if women were naturally moist and possessed an insatiable and unrivaled sexual drive that threatened men, it stands to reason that suppression of female sexuality (both in practice and in literature) further served to subordinate women. If women were only permitted to engage in sexual activity once they were possessed by a man in marriage or taken by one forcibly through an act of rape, then we can conclude that the lack of sexual activity (virginity, chastity) implied passivity, as it adhered to women's appropriate passive role in medieval society. Why then does Christine de Pizan not present her heroines as sexually active and free to challenge the assumption that female sexuality needed to be oppressed? One possible explanation, I argue, is that Christine is recoding female sexuality (or the lack thereof), aligning virginity and chastity with female authority and militancy.

The writer's treatment of Queen Zenobia is representative of this very strategy. As a girl, Zenobia is described as chivalrous, brave and strong. Fearing nothing, the young Princess hunts lions, bears and all manner of ferocious beasts. Her physical strength and courage designate Zenobia as somewhat atypical, being both an image of feminine nobility and beauty and of masculine-like strength. However, Christine also presents Zenobia's virginity as central to her identity: "Cette vierge méprisait tout amour charnel et fut longtemps rebelle au mariage, car elle souhaitait se garder intacte sa vie 
durant" (La Cité 81). Eventually, Zenobia is forced to marry and produce offspring; however, following the assassination of her husband, she takes control of both the kingdom and its army and returns to a state of chastity. Once more, Christine lauds Zenobia for her ability in battle, stating that she far surpassed even the most talented knights in the art of war. In the same paragraph, she reiterates Zenobia's sexual restraint: "Elle fut d'une chasteté exemplaire, car non seulement elle évitait les autres hommes, mais elle ne couchait avec son mari que pour assurer sa descendance" (83). By placing these markers of the Queen's greatness within the same thought in both instances, Christine is presenting her heroine's military prowess and sexual restraint as equally significant to her identity. We saw a similar authorial choice in the relationship between Minerva's invention of armor and the defense of her virginity, as well as Christine's use of passive nomenclature when referring to Joan of Arc's military accomplishments.

This use of virginity and chastity, whose values are closely aligned with the oppression of women in medieval society and their representation as passive in literature, further demonstrates how Christine de Pizan systematically re-contextualizes female passivity. The writer uses passive language and traits associated with submission and passivity to underscore her heroine's activity.

\section{The Maternal Body as an Instrument of Rebellion and War}

While the previous two categories demonstrated how Christine de Pizan recodes passive language and traits to represent her heroines, as well as how the author uses the masculine body to justify her warring women and demonstrate their shift from passivity to activity, the following category will examine Christine's treatment of the female body. 
Specifically, I will focus on the author's use of the maternal body as an instrument of both rebellion and war.

The image of the mother in Christine de Pizan's writing is fraught with complexities and tension. In the opening of the Cité, Christine-protagonist's mother symbolically interrupts her daughter's studies to call her down to dinner. Maureen Quilligan has noted how this scene embodies the conflict Christine-protagonist faces between the female body and role she is meant to fulfill, but rejects, and the scholarly life and education she seeks (“Allegory and the Textual Body" 229-30). Renate BlumenfeldKosinski makes a similar observation, noting the connection between Christineprotagonist and Christine-author: "The mother's role is emblematic of the difficulties Christine perceived in her own career: how to combine a serious literary intent with being a woman in a society that valued nurturing, piety and passivity in women above all else" (289). Nonetheless, the Cité contains numerous examples of mothers who break the mold Christine (as both an author and character) struggles with, and who reinterpret the role and significance of the maternal body.

One such example is that of the Sabines, who, facing war between their captors (their husbands and fathers of their children) and their own fathers, place themselves and their infants between the two armies. As we have previously examined how Christine uses language to constitute these characters' shift from passivity to activity, I will only focus on the significance of their identities as mothers:

Celles qui avaient des nourrissons les prirent dans leurs bras pour les emmener avec elles; il y avait là une multitude d'enfants et de femmes enceintes... Elles se mirent alors entre les deux armées, de sorte qu'il fallait leur passer sur le corps pour se battre... Voyant leurs enfants et leurs 
femmes ainsi éplorées, les maris en furent bouleversés; ils n'avaient aucune envie, crois-le bien, de foncer sur elles. (174-75)

Although the Sabines are depicted as active in this scene - they function as the subjects of the action - ultimately, they return to a position of passivity; their husbands and fathers take pity on them, thus ending the battle. Grammatically, they become passive objects, however, by inciting pity, the Sabines also appear as helpless and vulnerable, further subjugating them in relation to the men. This vulnerability echoes a common belief of medieval Europe that motherhood weakened women, stripping them of their "capacity to fight" (Houston 163). Nevertheless, this scene does, in fact, align motherhood with violence and death and upsets literary tradition. While the Sabines never engage in the battle physically, they are prepared to sacrifice themselves and, with them, the descendence of both their fathers and husbands. From this perspective, the Sabines hold power over the fate of the men. This is not the first time that Christine de Pizan has chosen to give her heroines agency over their bodies; however, the scenario is unique given that the Sabines deliberately threaten violence against their pregnant and presumably also nursing bodies. In this sense, the Sabine women are using their bodies as figurative arms of war. When we consider that the rape and murder of women was a reality of war during the Middle Ages, their behavior constitutes a significant reversal of power. Maureen Quilligan has stated that Christine's unusual treatment of martyrdom in her works including the Cité serves as a unique validation of her own authority as a female author - pain and violence in the form of martyrdom are empowerment ("Rewriting the Body" 221-22). While these women cannot be categorized as martyrs for obvious reasons, I contend that one possible interpretation of the Sabines' story is that 
Christine is using a similar strategy to valorize her heroines' actions, albeit with a considerably more positive conclusion. Although the Sabines remain subjugated in relation to the men of their story, Christine de Pizan manages to use their passive position and more importantly their bodies - which, being the bodies of mothers, are necessarily tied to the male body, ${ }^{7}$ further emphasizing their subordination - to reinstate their authority. While the opening of the Cité presents a rather negative image of the domestic and limited authority of motherhood, the tale of the Sabines upends this assumption, demonstrating that the maternal body can both nurture and destroy.

A similar concept appears in the Ditié when Christine refers to Joan of Arc as the mother of France:
Considerée ta personne, Qui es une jeune pucelle, A qui Dieu force et povoir donne
D'estre le champion et celle
Qui donne à France la mamelle
De paix et doulce norriture, Et ruer jus la gent rebelle, Véez bien chose oultre nature! (lines 185-92)

What is perhaps most interesting about this stanza is Christine's representation of Joan as at once a warrior akin to biblical heroes Moses, Joshua and Gideon (to whom Christine compares Joan in the stanzas preceding and following this one) and a nursing mother. Kevin Brownlee has noted the extent to which this depiction of Joan "transcends previously operative gender distinctions," stating that the author presents the Maid of Orléans as a combination of heroic male and female identities ("Structures of Authority"

\footnotetext{
${ }^{7}$ Discussing motherhood, Julia Kristeva posits that although the maternal body ensures the continuation of humankind, it does so "under the sway of the paternal function" (304).
} 
137). However, I propose that Christine de Pizan places specific emphasis on Joan of Arc's feminine identity in this stanza - a tactic we have already seen through her repeated use of diminutives throughout the poem, as well as her frequent proclamations of wonder at Joan's achievements, because she is a woman. Once more, Christine reiterates that Joan is a mere pucelle before describing her abilities as a warrior. However, more striking in this stanza, is the effect of lines 189 to191, wherein Joan nurses France with peace and sweet milk, then proceeds to strike the rebels down. The reader is struck consecutively with an image of mothering and violence, albeit for a righteous cause. These lines recall the significance of the Sabine women placing themselves and their infants between their families' warring armies and thereby breaking the subordination of the maternal body by using its connection to male authority and fatherhood to gain power. Although Joan's motherhood is figurative, the consecutive nature of these lines appears to be a deliberate attempt to conjure the image of the warring maternal body - a fierce mother protecting her child. Furthermore, Christine does not imply that the Joan who nurses France is different from the Joan who casts down rebellious peoples; on the contrary, they are one in the same. In this stanza, Christine is not depicting Joan as possessing multiple gendered identities; the motherly body that nurtures her child is the same one that defends it. That Christine de Pizan does not separate Joan's identity as warrior and mother is important, because the image underscores the unique authority of the maternal body. As in the case of the Sabines, the mother both gives and takes life. As such, Christine is both celebrating and reclaiming the role that would seek to bind women to passivity. 
Our final example of Christine de Pizan's reinterpretation of the maternal body is that of the woman who nurses her mother in prison. I have previously examined how this woman uses her perceived weakness and inferior position as female to gain access to her mother and I will now focus on the way she saves her mother from starvation in prison:

Toutefois, avant de la conduire auprès d'elle, ils la fouillaient minutieusement pour s'assurer qu'elle ne lui apportait aucun aliment. De nombreux jours s'écoulèrent ainsi. Il apparut enfin impossible aux geôliers que la prisonnière ait pu survivre aussi longtemps sans manger; pourtant elle vivait encore... Ils espionnèrent donc la mère et la fille lors de la visite suivante et s'aperçurent que la pauvre fille, qui avait récemment accouché, donnait le sein à sa mère, qui buvait ainsi tout le lait de ses mamelles. La fille lui rendait donc en sa vieillesse ce qu'elle lui avait pris en son enfance. (La Cité 143)

The importance of this anecdote lies within its departure from the previous two examples studied. Unlike Joan of Arc and the Sabines, this woman's identity as a mother is not aligned with war and/or violence. Instead, Christine presents this character as uniquely active because of her body and within her role as a mother. In addition, Christine de Pizan presents us with a traditional use, as it were, of the maternal body that, nonetheless, separates itself from the inherent connection to the male body that subverts maternal authority. Julia Kristeva posits in her theory of the homosexual maternal-facet that the desire for motherhood is also driven by a "nonpaternal causality" (305). She proposes that: "By giving birth, the woman enters into contact with her mother; she becomes, she is her own mother; they are the same continuity differentiating itself' (305). By nursing her starving mother back from the brink of death - returning what she took from her this young woman echoes the notion of continuity within motherhood. 
While in the previous two examples Christine rendered the maternal body active and independent by disrupting the role she had deemed problematic and limiting in the opening of the Cité, in this tale she demonstrates the unique power of the maternal body through gender-appropriate behavior. The act of nursing becomes an act of rebellion literally because this young woman defies her mother's sentence to death by starvation and dehydration, but also figuratively. If we accept the necessary relationship of subordination between motherhood and fatherhood, then this young mother subverts her inherent passivity by using her body to ensure the survival of motherhood, instead of the continuity of the male descendance.

Central to all three of these examples are the acts of nurturing and nursing; in a very literal sense in the latter two stories and in an indirect sense in the tale of the Sabines. While both nursing and nurturing constitute active roles (grammatically and in practice), they are tied to motherhood, which has historically been viewed as a passive position, as Christine de Pizan suggests in the opening of the Cité and as Maureen Quilligan, Renate Blumenfield-Kisinski and Nancy Houston have reiterated in their research. By representing the maternal body as 1) capable of both receiving and performing acts of violence and war and 2) able to defy motherhood's inherent tie to fatherhood through role-appropriate behavior, Christine de Pizan essentially reinterprets the role of the mother, assigning agency and power to the maternal body that society in 
fifteenth-century France viewed as necessary for the continuation of humanity and yet always incomplete and lacking. ${ }^{8}$

At the opening of this chapter I presented the idea of a passive heroine, which is seemingly oxymoronic. However, when we examine some of Christine de Pizan's atypical heroines, we can understand how the author uses language, gendered characteristics as well as the body to subvert typical notions of passivity and activity. Nearly each of the women discussed shifted throughout their stories between grammatical passivity and activity, meaning that they were at different points the object and subject of activity. Christine de Pizan frequently accomplishes this shift through a physical transformation of her heroine, such as Hypsicratea, who becomes active as her body becomes that of a strong knight. This use of the masculine as active appears to be a means of validation of women participating in gender-transgressing roles (as is the case with Hypsicratea and Minerva as warrior women). Nevertheless, when Christine de Pizan physically transforms her heroines to validate their active positions, she is still prescribing to traditional definitions of these roles - it is only through these women's performance of the male gender that they become active. However, the author's use of language and the female body becomes more complex when she uses traits associated with passivity to facilitate her protagonists' activity. Christine presents weakness and positions of inferiority and passivity as sources of strength and authority. This is demonstrated through her use of diminutive language, her heroine's displays of

${ }^{8}$ Elizabeth Robertson states that medieval medical opinions of reproduction, spearheaded by Aristotle's work, gave evidence for the "existence of the male seed alone," positing that as the female body represents the passive, it does not merit the active role of creation (144). 
helplessness and the author's unique treatment of the maternal body. Through these authorial decisions, Christine de Pizan reinterprets the significance of passivity and activity; she severs the accepted connection between the passive and the lack of authority and agency. Furthermore, as is the case with Queen Hypsicratea, the Sabines and the woman who nurses her mother in prison, Christine presents her audience with the possibility of activity within a role of passivity. All of these women ultimately remain subordinated - Hypsicratea in relation to her husband, the Sabines in relation to their husbands and fathers and the unnamed woman in relation to the guards as well as the male judges who finally free her mother. Despite this, Christine grants these women agency and activity within their passive roles. However, such a concept becomes complicated when religion enters the equation. In the following chapter I will examine the implications of religion on Christine de Pizan's Christian heroines, to determine how the role of God affects the agency and independent power Christine bestows upon them. 


\section{Chapter II}

\section{Religious Subordination: Do Christine's Christian Heroines Own their Actions?}

The previous excerpts from Le Livre de la cité des dames and Le Ditié de Jehanne d'Arc demonstrate a shift in traditional definitions and implications of passive and active identities in literature. Christine de Pizan achieves this through her use of language, gender specific traits and presentation of the female body. However, it is important to note that up until this point, my examination of Christine's reinterpretation of the passive and active has been limited to largely secular relationships of power and oppression between men and women. I included Joan of Arc in this discussion, owing to Christine's deliberate treatment of Joan's sex as essential to her heroic identity. Nonetheless, I do not wish to imply that Christine's pointed attribution of Joan's authority to God is superseded by her sex. In fact, Joan's position in relation to God has been the subject of much discussion, many scholars arguing that the Maid's religious subordination is paramount to her identity - she is the passive vessel of God. Such an assumption, however, raises further questions about the possibly nullifying effect of divine intervention.

This second Chapter will provide an analysis of religion and God as sources of subjugation and will determine to what extent, if any, the relationship between Christine's Christian heroines and God invalidates their agency and positions as active literary figures. I will structure my discussion similarly to that of the previous chapter by drawing from specific excerpts from the Cité as well as the Ditié to assess the language, historical and hagiographical contexts of the examples. As in Chapter I, I have chosen to 
divide the following discussion into sections to clearly address each topic. I will open my examination of religion and literary activity by addressing the interpretation of Joan of Arc as a passive vessel of God's will, in which I will also refer to Giovanni Boccaccio's The Fates of Illustrious Men to support my argument that religious subordination is not unique to Christian heroines. In the following section, I will expand my discussion to Christine de Pizan's martyrs and saints included in Part III of the Cité, approaching this analysis from a perspective grounded in medieval French hagiography's treatment of gender. My final section of this chapter will address the question of age, specifically maidenhood, as it pertains to the women studied in the previous two sections.

\section{Joan of Arc: God's Passive Vessel?}

To begin my investigation, I will briefly outline the interpretations of the Ditié that posit that Joan of Arc is depicted as God's passive vessel, rather than a traditional, active heroine. These analyses are, for the most part, grounded in historical and linguistic arguments. In her study of heroism in the Dité, Rosalind Brown-Grant states clearly what appears to be the main historical reasoning behind interpreting Christine's Joan as passive - that Christine deliberately diminishes her heroine's authority in relation to God for political gain:

Rather, though Christine, like Warner, stresses Joan's dynamism, she, in effect, rejects Warner's criterion of independence of action as a key component of heroism. Indeed, Christine ultimately subordinates her celebration of Joan as an exemplary member of the female sex to her depiction of the Maid as an atypical woman whose actions are determined by her role as instrument of God. Although to the modern mind this strategy...might seem paradoxical, for Christine it was completely logical, given the very precise political purpose for which she created her text. (127) 
This conclusion postulates essentially that Joan of Arc cannot be active because such a representation of female agency would have been deemed too far-fetched to be accepted by a patriarchal French government and monarchy, thus undermining the importance of Joan's mission. As a result, Brown-Grant argues that Christine de Pizan chose to mask Joan's importance as an icon of uniquely female strength, to convince France to accept the woman whom she believed to be the true salvation of the country: "These deeds are proof that Joan has divine backing, which is the reason the country should unite behind her..." (128). Brown-Grant certainly does not deny that the Ditié also pays homage to the capacities of the female sex; however, in her work she contends that Joan is not the active heroine she appears to be at first glance but rather a tool of political propaganda.

A second argument for Joan's passivity arises in the examination of the language of the Ditié, which Kevin Brownlee studies at length in his chapter, "Structures of Authority in Christine de Pizan's Ditié de Jehanne d'Arc." In it, he posits the impossibility of an active Christian heroine, referencing the Cité and Christine de Pizan's treatment of female martyrs: "While exemplary female warrior figures are systematically valorized, there is no overlap of the component 'warrior' with the component 'Christian.' The heroism of exemplary Christian women is fundamentally passive" (132). Therefore, Joan of Arc as God's chosen heroine, remains passive; grammatically passive in relation to God and further subordinated by her position as a Christian heroine. However, unlike Brown-Grant, Brownlee does not view the political agenda of the Ditié as paramount to the poem's meaning, he instead suggests that Christine de Pizan presents the success and merit of Charles VII's reign as dependent on his acceptance of the Maid of Orléans, 
which prioritizes Joan's authority over the King's. Nonetheless, her authority stems from her being what Brownlee describes as the "active object" in relation to Charles VII, the "passive subject" ("Structures of Authority" 135). While Joan is active in relation to King Charles, her connection to God objectifies her existence - she is God's instrument as well as his miracle - while Charles VII, although passive, retains a sense of agency.

I will first address the conclusion drawn by Rosalind Brown-Grant - that

Christine de Pizan subordinates her heroine to serve the greater good and to convince the French monarchy and people to accept a female military leader. Two stanzas in particular challenge this interpretation:

Des Sarradins fera essart, En conquerant la Saintte Terre. Là menra Charles, que Dieu gard!

Ains qu'il muire, fera tel erre.

Cilz est cil qui la doit conquerre.

Là doit-elle finer sa vie,

Et l'un et l'autre gloire acquerre.

Là sera la chose assovye.

Dons desur tous les preux passez,

Ceste doit porter la couronne,

Que plus prouesse Dieu lui donne

Qu'à tous ceulz de qui l'on raisonne.

Et n'a pas encor tout parfait!

Si croy que Dieu ça jus l'adonne,

Afin que paix soit par son fait. (Le Ditié, lines 337-52)

In the above stanzas, Christine prophesizes the futures of both Joan and Charles VII, presenting them as equals, at least grammatically. The use of the term l'un et l'autre in line 343 suggests that their destinies are of equal significance and yet distinct; they will each achieve a separate glory. It is also important to note that in this stanza, Joan's future glory is not tied to God. Christine de Pizan could have framed these lines differently, 
attributing Joan's final accomplishments to God, as she does in many stanzas preceding and following this one. However, she does not, making her choice to equate Charles VII and Joan, and to predict their separate success, even more significant. The stanza that follows demonstrates an equally striking choice of language on the part of Christine de Pizan when she states that Joan of Arc must wear the crown. This crown Joan is meant to carry is almost certainly a metaphoric one - the highest form of honor - as Christine declares that Joan is superior to tous les preux - the biblical heroes to whom she has compared the Maid - who have come before her. Christine never suggests that Joan is better fit to rule than Charles VII. Certainly, the fact that Christine does correlate Joan's valiance and merit of such an honor to God grammatically subordinates her; however, in this instance this connection does not detract from the power of the image Christine de Pizan paints of Joan's future coronation amongst heroes. No doubt readers of the Ditié would have remarked the pointed use of such a potent symbol of royalty; whether this would have discouraged or encouraged their support of the female military leader is unclear. Nevertheless, the effect of this line remains the same: Joan is to be crowned in her own right.

The previous two stanzas present us, then, with a Joan of Arc who will, according to Christine de Pizan's predictions, find glory in the Holy Land that is distinct from the glory Charles VII will achieve, and will be crowned, albeit metaphorically, above all other heroes both male and female. While I do not wish to suggest that Joan of Arc is not frequently represented as grammatically passive in relation to God, as both Brown-Grant and Brownlee are correct on this front, I posit that these two stanzas provide evidence 
that questions the assumption that Christine de Pizan chose to subordinate her heroine in the hopes of convincing France to accept her. Rosalind Brown-Grant references Marina Warner's heroic criterion, which include the traits of dynamism and independence. Brown-Grant contends that while Joan of Arc displays dynamism, her passivity in relation to God indicates that she is not independent (125). However, the Joan of Arc that Christine de Pizan presents to her readers is of the past, present and future, the last of which does appear to achieve a level of independence; Joan's future is not as clearly linked to the Ditié's political agenda.

The question of independence as a defining feature of Joan's authority (or the lack thereof), presents itself once more in Kevin Brownlee's work. As has previously been noted, Brownlee structures his interpretation of Joan of Arc's authority around the notion that Christian heroines are, by design, passive. He, too, draws attention to Joan's (grammatical) subordination under God and posits that while Joan is active in relation to Charles VII, she is the object rather than the subject of Christine de Pizan's language ("Structures of Authority" 132, 135). Essentially, Brownlee is suggesting that both in language and context, Joan lacks independence.

If we accept that Christian heroines are necessarily passive, should we not assume that the same is true of Christian heroes? And if not, why then does this apply uniquely to Christian women? The Ditie itself provides us with an answer to this question in Christine de Pizan's treatment of the biblical heroes Moses, Joshua and Gideon:

Que puet-il d'autre estre dit plus Ne des grans faiz des temps passez? Moÿses, en qui Dieu afflus Mist graces et vertuz assez, 
Il tira, sans estre lassez,

Le peuple de Dieu hors d'Egipte

Par miracle. Ainsi repassez

Nous as de mal, Pucelle eslite! (lines 177-84)

Moses, like Joan, functions as the intermediary of God in this stanza; his heroism is not

directly attributed to his being male or his character. On the contrary, his virtue and grace are owed to God and he leads the Egyptian people to safety by miracle - divine intervention. Joshua appears to be no different:

Car, se Dieu fist par Josué

Des miracles à si grant somme,

Conquerant lieux, et jus rué

Y furent maint, il estoit homme

Fort et puissant... (lines 193-97)

While Christine links Joshua's strength and power to his gender, she does not do so with his heroic achievements. In fact, in this stanza, Joshua takes the place of the active object - he is the instrument through which God carries out his missions, thus, rendering his authority passive. The same is true for Gideon: "Et Dieu le fist, ce dit le conte, / Combattre, ne nul n'arrestoit / Contre lui, et tout conquestoit" (lines 211-13). God makes him fight; Gideon does not own his actions. As such, he too is a passive hero. Christine's treatment of biblical heroes, at the very least then, does not differ from her treatment of Joan of Arc - they are all in some shape or form the instruments of God. However, before continuing to a discussion of whether Joan's figurative authority differs in some way from that of her male counterparts, I would be remiss to examine only those examples found in Christine de Pizan's work.

While Giovanni Boccaccio is perhaps best known for his works the Decameron and De Claris Mulierbus (Concerning Famous Women), both of which served as the 
models and points of departure for Christine's La Cité des dames, he also penned De Casibus Virorum Illustrium (The Fates of Illustrious Men). This collection of stories functions as the counterpart to De Claris Mulierbus, detailing the moral lessons of the falls of great and heroic men. One such tale is that of the Roman orator Marcus Tullius Cicero whom Boccaccio lauds not only for his eloquence of speech but his ability to save the city of Rome from corruption and nefarious plots through oration. Throughout this tale, Boccaccio remarks upon Cicero's greatness which he largely attributes to Cicero's character and gender, stating that he "showed the heart of a man" early on in life, indicating that he possesses an innate sense of honor (160). However, the skill that earns Cicero his fame and status as the "protector of Rome" is not associated with his gender: "Cicero, it seems to me, was sent here from God and already possessed genius from Heaven, yet working with continuous diligence he became so eloquent that he surpassed Plotinus Gallus of Cybelia...” (161-62). Despite ascribing his honor to Cicero's quality as a man (presenting him as active) Boccaccio decides to write his hero as grammatically passive in relation to God, who bestows upon him the talent of speech. Nevertheless, it is important to note that Boccaccio then gives Cicero agency in stating that his superiority is due to Cicero's diligence. This suggests that the writer does not intend to imply that Cicero lacks authority; his accomplishments are connected to God, but they are his own.

A similar concept appears once more in Boccaccio’s work during an imagined conversation between the author and Francis Petrarch, in which the latter scolds Boccaccio for wasting his God-given talent: "Why do you attempt by laziness to take away what perhaps God, by your work, wishes to offer to others?” (205). While not an 
explicit demonstration of the passive hero, Petrarch's question returns to Kevin Brownlee's notion of the active object; Boccaccio is God's tool, but still maintains a level of independence. It is Boccaccio's action - writing - that disseminates God's messages. The language of Boccaccio's text separates God's authority from that of the heroes in such a way that allows them to retain agency and independence, despite being passive in relation to God.

Returning to Joan of Arc and Christine de Pizan, the question must be posed: is Joan's authority solely dependent on God's will, or, does Joan own her authority? While there are numerous stanzas in which Christine invokes Joan's strength which, she contends, is made all the more miraculous by her sex, to properly address this question, I would like to refer to one final stanza of the Ditié in which Christine marvels at the serendipity of Joan of Arc's birth. The language Christine de Pizan employs while referring to Joan as a person, rather than the incredible actions that define her person, provides an essential insight into the perceived dependency of the Maid's identity on God's will.

Tu, Jehanne, de bonne heure née, Benoist soit cil qui te créa! Pucelle de Dieu ordonnée, En qui le Saint Esprit réa Sa grant grace, en qui ot et a Toute largesse de hault don, N'onc requeste ne te véa.

Qui te rendra assez guerdon? (lines 169-76)

It is possible to draw a parallel between Christine's language in this stanza and that of Boccaccio's in his rendition of the tale of Cicero. The latter is depicted as being sent from God and possessing genius and gifts bestowed upon him by Providence. Joan's birth has 
been ordained by God and similarly, Joan receives her grace and ability from the Holy Spirit. Thus Joan, like Cicero, is the perfect creation of God; but does Christine's language suggest that she is also merely his puppet? The last two lines of this stanza appear to indicate that she is not. In line 175 the author of the Ditie distinctly gives her heroine agency in stating that Providence has never refused her any request. While in comparison to much of the poem this line is fairly simple and appears to be of little consequence, by presenting Joan as asking favors of God, Christine creates an independent character, with wants and needs that she acts upon - she gives Joan some agency over the mission she is destined to accomplish. The following line emphasizes this; Christine de Pizan insinuates, by demanding who will be able to repay you (Joan of Arc), that the heroine is the deserving object of France's praise and gratitude, not God. I am not suggesting that Christine de Pizan wished to diminish God's greatness as she indicates throughout the Ditié that the French people should trust and thank God for blessing France and appointing Joan as its savior. However, knowing this underscores the importance of the line. Within the same stanza Christine de Pizan both proclaims that Joan's greatness is Heaven-sent and presents Joan as independent. This particular portrayal of a Christian heroine again reflects the image Boccaccio paints of Cicero, a Christian hero. While their talents and accomplishments are intimately linked to divine power, they nonetheless possess agency over their actions.

It stands to reason that Christine de Pizan does distinguish, to an extent, Joan's identity and therefore her actions, from God. The three stanzas studied demonstrate that the author of the Ditié intentionally gave her heroine agency and authority. Christine 
predicts a future in which Joan achieves glory equal to that of Charles VII's and is crowned superior amongst her kind. Furthermore, the author of the Ditié indicates that her country's gratitude is owed to Joan alone. In each of these instances, Christine solidifies Joan's identity as not only the pucelle of God but as a historical heroine in her own right.

Despite this, the fact remains that Joan is subordinated under God and maintains a position of grammatical passivity in relation to divine powers throughout the Ditié. I contend that this does not imply that she is wholly passive. By studying examples of male heroism and greatness both in the Ditié as well as in Boccaccio's De Casibus Virorum Illustrium, it becomes clear that religious subordination is not gender-bound. Christine de Pizan pointedly portrays Moses, Joshua and Gideon as vessels through which God works, even going so far as to state that God made Gideon fight, effectively stripping him of agency over the actions of his own body. Like his female counterpart, Boccaccio presents his Christian heroes (including himself) as either the passive subjects or active objects of God's will. Notwithstanding grammatical passivity, Boccaccio makes a point of differentiating his hero's authority from that of God's and allows him to maintain agency over his person and his actions, just as Christine does in the case of Joan of Arc. Therefore, it stands to reason that while Christian heroism (not merely pertaining to heroines) may necessitate the subordination of the hero or heroine under God according to Christian principles, a distinction can and should be made concerning the implications of this passivity on the literary and historical authority of heroic figures. 


\section{The Holy Couple}

This separation of necessary passivity within Christian heroism and the independence of said heroes and heroines may be expanded upon further through a hagiographical lens. In fact, an examination of gender, and the treatment of saintly women in particular, reveals that the necessary passivity of the Christian heroine may only hold true from a grammatical standpoint. The Christian belief that saintly women maintain the role of Christ's bride, thereby forming the holy couple and serving as an essential intermediary between humanity and God, offers a possible explanation to this exception. Karl D. Uitti explains the unique privilege that this relationship accords holy women:

Given woman's identification as humanity, or church, as bride of Christ, it follows that, to the extent an individual woman on earth, in saintly fashion, remains steadfast and faithful to her very privileged role as indispensable member of the couple she and he form, her power is, in very significant ways, much the stronger of the two members of the purely human pair of male and female. (251)

Therefore, the relationship between the female sex and God is not as clear-cut of a hierarchy as one would assume. Stating that the saintly woman is indispensable to the holy couple, signals that women maintain a privileged position in relation to God. This is not to say that Christianity presents God and women as equals, only that within the holy couple women are accorded a unique authority.

How then does this approach change or inform our interpretations and understanding of Christine de Pizan's saints and martyrs whom the author portrays as heroines of their faith and/or sex? To investigate this, I will draw upon two chapters from Part III of La Cité des dames, specifically the lives of St. Catherine and St. Christine, 
both of whom chose violent death over abandoning their devotion to God. Before continuing, however, I would like to emphasize that the relationship between God and holy women cannot be applied to merely Christian or pious women. Uitti stresses that these women must be "generally recognized or, in some discernibly authoritative manner, named as holy - saintly..." (247). For this reason, it would imprudent to conclude that all of Christine de Pizan's Christian heroines are inherently privileged.

While Part III of the Cité contains decidedly fewer examples of heroic women in the traditional sense (i.e. warriors), the instances of graphic violence towards the female body are certainly more frequent - nearly every tale depicts the torture and/or execution of young women. Furthermore, Christine de Pizan presents the city's martyrs and saints as warriors in their own right - warriors of the Christian faith. Therefore, it follows that these holy women may be included under the banner of Christine's heroines. Saint Catherine in particular is portrayed as a savior of God's people under the tyrannical emperor Maxence and is identified at the outset of her chapter as forming the holy couple: "Elle était chrétienne et refusait tout mariage pour se consacrer à l'Époux celeste" (242).

Curiously, Catherine's heroism is passive in a very literal sense. She does not use her earthly body to save the converted philosophers whom the Emperor attempts to burn, nor to inflict violence upon him, nor even to save herself; Saint Catherine's sole acts throughout her story are speech, prayer and self-sacrifice through inactive resistance. Nevertheless, Christine frames her narrative to indicate clearly that Catherine is responsible for the philosophers' reception amongst the martyred saints of heaven. "Mais 
cette sainte vierge les encourageaient dans leur martyre et les assurait qu'ils seraient reçus au paradis éternel, tout en priant Dieu de les maintenir en sa sainte foi; c'est ainsi qu'ils furent accueillis au nombre des saints martyrs grâce à la bienheureuse Catherine" (242). In this instance, as well as in a following scene in which God converts a mob of people upon the decapitation of Emperor Maxence's wife, Christine de Pizan deliberately presents God's acts of salvation and conversion as carried out on behalf of Saint Catherine (243). This cooperation, for lack of a better word, between Saint Catherine and God differs substantially from the examples of Joan of Arc and Christine's biblical heroes I examined earlier in this chapter, who, while retaining a level of agency over their actions, are subordinated in relation to God. In the case of Saint Catherine, no such subordination occurs; while her earthly body remains passive, Christine indicates that Catherine's action and power manifest themselves through God's will. She is not God's vessel, but his spouse. Christine de Pizan was apparently not the only author to write the Saint's story in this manner. Studying the twelfth-century writings of an "Anglo-Norman Benedictine nun Clemence of Barking Abbey," Karl D. Uitti notes that Saint Catherine plays a decidedly active role: "Catherine defeats Maxence...Consequently, it is she who completes the Christianization of the Roman empire" $(254,256)$. It is possible, I argue, to assume that saintly Christian heroines are not necessarily passive but are necessarily active.

The tale of Christine de Pizan's patron saint, Saint Christine, provides us with more compelling evidence to support the above conclusion. Similar to Catherine, Saint Christine denounces marriage and the false idols of her father's faith, devoting her life 
and body to God and Jesus Christ (La Cité 256). What follows is the graphic description of the violence and torture Saint Christine's father forces her to suffer, counteracted by the many miracles God performs again, on behalf of Saint Christine. "Elle demanda à Dieu de faire tomber l'idole et de la réduire en miettes, ce qui fut fait. Plus de trois mille personnes se convertirent alors, tant pour les paroles de cette vierge que pour les miracles faits en sa faveur" (259). Once more, Christine de Pizan explicitly links divine power with that of her heroine; Saint Christine is active and powerful through her relationship to God. Furthermore, while Saint Catherine's body remains relatively passive throughout her story, the body of Saint Christine serves as an integral tool of the young girl's fight against her father and the three judges who attempt in vain to force her to renounce God. In her final act of resistance, Saint Christine spits her severed tongue into the eye of the judge, Julien:

Ils lui tirèrent alors la langue et la coupèrent jusqu'à la racine, mais Christine cracha sa langue au visage du tyran et lui creva un oeil. Puis elle lui dit, plus clairement que jamais: "A quoi cela te sert-il, tyran, de m'avoir coupé la langue pour l'empêcher de bénir le Seigneur, quand mon âme le bénira pour l'éternité et que la tienne sera Maudite à tout jamais! Puisque tu n'as pas cru ma parole, il était juste que tu sois aveuglé par ma langue. (261)

This passage is significant, first and foremost, because Christine de Pizan chose to narrate this portion of the chapter through the voice of her patron saint, emphasizing her activity in a very conventional sense and demonstrating her heroine's agency over her own body (and voice), an authorial choice we have seen in many of the previously studied heroic women. Thus, Saint Christine's power becomes not just spiritual, but very physical; her body is equally capable of producing the miracles (glorious or spiteful) that God also 
carries out for her through divine intervention. Moreover, it is important to note that the saint's use of her body and her voice is independent, but still empowered by her position in relation to God. Analyzing the relationship between Saint Christine's authority and that of the writer, Kevin Brownlee comments on this scene: "The onomastic link here figures the spiritual link of authorization... Because of her divinely conferred baptismal name, she literally speaks "ou nom de Jhesu Crist"” ("Martyrdom and the Female Voice" 123). Saint Christine's body and voice embody divine authority; however, God does not speak or act through the saint, she does so on behalf of him, just as God speaks and acts on behalf of Saint Christine.

As has previously been noted, the power accorded to saintly women through their privileged relationship to God was generally accepted in the Christian faith and documented in medieval hagiography. Notwithstanding these facts, Karl D. Uitti reminds us that the majority of medieval literature and historical documents told a different story: "traditionally (i.e., in most ecclesiastical redactions of history), these women were not seen as so central to the historiographic process as, say, Saint Peter and Saint James were" (265). The influence and power of these women was largely downplayed in authoritative texts during the Middle Ages. Knowing this renders Christine de Pizan's focus on the historical importance of her Christian martyrs, and her choice to represent them as the right hands of God, all the more poignant to the discussion at hand. The Cité's women saints and martyrs, such as Saint Catherine and Saint Christine, are not only to be revered because they gave their lives for their faith, thus demonstrating their loyalty to God, but because their acts were, in fact, vital to the perpetuation of 
Christianity. Christine de Pizan makes it clear that the millions of conversions and miracles that surround the sacrifices of Saints Catherine and Christine are owed to the power shared between God and these saintly women - a power and authority only attainable by the female sex. Christine de Pizan is, then, doing what historical accounts at the time did not - depicting women saints and martyrs in their rightful, active, historical roles.

This brings me to my final point regarding the significance of the holy couple in Christine de Pizan's writings. I posited at the outset of this section that the notion of an inherent passivity in Christian heroines may only hold true grammatically, given that the concept of the holy couple formed by God and saintly or holy women elevates the latter to a level of privileged equality. This assumption is both true and false. It is true that Saint Catherine's body is presented as passive throughout her chapter - she does not fight, resist, or inflict violence upon her torturers. Instead, her activity is represented through the miracles God performs in her name as well as through her voice - she prays to God to act on her behalf and encourages the martyrdom of those put to death for their betrayal of the emperor. Therefore, there is passivity within Saint Catherine's heroism. However, I argue, this passivity is not inherent to saintly Christian heroism; Saint Christine's life demonstrates this; both her body and voice facilitate the martyr's activity. Saint Christine uses her mutilated body to physically harm the judges, and her voice both invokes the power of God while maintaining its own authority. Finally, Christine de Pizan repeatedly states throughout the lives of Saint Catherine and Saint Christine that God punishes their torturers and converts thousands en la faveur of the young martyrs. 
This choice of language further points to the two saints as holding an elevated position far above that of men - in relation to God. Therefore, it would seem that passivity is not a dominating trait of saintly Christian heroism and is perhaps the exception rather than the rule.

\section{Maidenhood and Authority}

A defining characteristic shared between Joan of Arc, Saint Catherine and Saint Christine is their designation as young virginal women - maidens. In Chapter I, I discussed Christine de Pizan's use of virginity and chastity to validate her secular heroines' authority, making up part of her strategy to recode feminine roles associated with passivity and subordination. I would now like to address maidenhood, of which virginity is an important facet, in the context of Christine de Pizan's Christian heroines. Let me begin by first establishing what is to be understood when I speak of maidenhood. According to Kim M. Phillips, from approximately the fourteenth century onwards in Europe, maidenhood was seen as the transitional period from childhood to adulthood (and presumably motherhood) starting with a girl's first menstruation and ending once the girl was given in marriage to her husband. This transitional time started around the age of twelve and typically continued until fourteen or fifteen, but it was not uncommon for older adolescents, ages sixteen to eighteen, to still be considered maidens $(23-4,47)$. Maidenhood also held a particularly Christian significance in medieval European culture, as it was seen as women's peak or ideal age. Phillips states that while men's peak age reflected the age at which Christ began preaching - thirty - that of women reflected the Virgin Mary as she is depicted at "her death, assumption and coronation" - a youthful 
maiden and not an aging woman (43). Furthermore, maidenhood signified "an age in which sexual desirability and virginity are intermingled" (46). Interestingly, this unique coincidence of innocence, purity and sexuality appears to also have implications on the formation of the privileged holy couple I addressed in the preceding section. Kathleen Coyne Kelly describes this connection: "The body of the female virgin and the body of the Church came to be equated often enough in patristic texts with female virginity. Jerome avers that 'no vessel of gold or silver was ever so dear to God as the temple of a virgin's body'..." (137). Thus, during this vulnerable period of transition, girls were at once seen as sexually desirable and as maintaining a deeply intimate relationship with God as not merely his spouse but his earthly temple.

It stands to reason, then, that Christine de Pizan's emphasis on her Christian heroines' young ages may also be interpreted as part of the writer's strategy to validate and justify their distinct authority and as part of her attempt to recode female roles. Take this excerpt from Saint Christine's life, in which the judges drag her out into the streets by her hair, for example:

Quand le faux juge, plein de colère, vit que tout cela ne servait à rien, il la fit prendre sur la place publique par les cheveux, qu'elle avait longs et blonds comme l'or. Les femmes accoururent auprès d'elle et pleurèrent de pitié de voir torturer de la sorte une si tendre jouvencelle. Elles protestèrent contre le juge en criant: "Félon plus cruel qu'une bête sauvage! Comment un coeur d'homme a-t-il pu inventer tant de cruautés contre une si belle et tendre jeune fille?" (La Cité 258-59)

This scene stands out for several reasons: first and foremost, the description of Saint Christine's beauty and her young, tender age is juxtaposed with the graphic torture the judges subject the girl to both preceding and following this section. This stark contrast in 
imagery suggests that Christine de Pizan intended for her readers to take note of her heroine's maidenly physical appearance and perhaps its symbolism. Specifically, Saint Christine's long golden hair holds significance not only as a traditional symbol of feminine perfection and desirability, but as a symbol of the maiden, indicating that the girl remains pure and untouched (Phillips 49). The image of the pure maiden is strengthened through her crowning by Jesus Christ in the preceding paragraph: "Il lui donna son propre nom, l'appelant Christine, puis la couronna et lui mit au front une étoile replendissante..." (La Cité 258). Saint Christine wears a crown like so many of history’s martyred virgins, one that represents her religious status as well as her fate. Phillips explains the martyr's crown, using the popular tale of the Pearl Maiden as an example: "The symbolism of their crowns or garlands is more complex. As with the Pearl Maiden, they symbolize virginity and dedication to Christ...But they are also crowns of martyrdom" (49). The intimate and empowering connection of the holy maiden and Christ thus dominates Christine de Pizan's retelling of her patron saint's life.

While the highly symbolic depiction of virgin martyrs is not unique to the author of the Cité, I posit that we may read this symbolism as functioning similarly to Christine's reinterpretation of the maternal body and female tropes such as weakness and naivety and/or innocence often associated with passivity. In the case of Saint Christine, her beauty and purity dupe the women who attempt to save her from the wrath of the judges by bringing her to worship their false idols. Saint Christine concedes to their wishes at first, but quickly convokes God to cast down the false idols and the power of her speech causes the earth to tremble (259). The reader is thus presented with the image 
of a very feminine and fragile young girl, helpless at the mercy of her torturers, but one who is also capable of supernatural strength and possess the authority to evoke the ire of God. Consequently, the power of Saint Christine's maidenly identity becomes twofold: it serves as a validation of her authority and a tool of her activity. Christine de Pizan uses the privileged relationship between God and the holy maiden to justify unequivocally Christine's status as a heroine of her faith, whilst using the pagan women's presumption of the girl's helplessness and passivity, reflected by her tender age and physical appearance, to underscore her strength and activity in the scene that follows.

Saint Catherine's maidenhood appears to represent a similar dual authority. Christine de Pizan emphasizes her heroine's age, eighteen, going so far as to even align it with ignorance before subverting its passive connotations, all while simultaneously depicting her maidenhood as symbolic of Catherine's devotion to God and her identity as Christ's bride. Two excerpts from Catherine's chapter in Le Livre de la cité des dames illustrate the author's use of maidenhood as authority clearly, the first of which describes the philosophers' reaction when the emperor calls them to the city to dispute theology with the young Princess:

L'empereur fut stupéfait d'entendre parler avec tant d'autorité cette belle et noble vierge. Il ne sut que répondre, et se mit à l'examiner attentivement. Il manda alors les philosophes les plus renommés de l'Égypte, terre où leur discipline était fort à l'honneur à l'époque, et en ressembla plus de cinquante. Ceux-ci furent tout offusqués d'apprendre pourquoi on les avait convoqués, disant qu'il était bien futile de les avoir fait venir de si loin pour disputer avec une toute jeune fille. (242)

Here, Christine de Pizan appears to use her heroine's age similarly to her use of the diminutive, identified by Nadia Margolis and Kevin Brownlee, in Le Ditié de Jehanne 
d'Arc a quarter-century later: to emphasize the miraculous feat of Saint Catherine's authority over these highly influential and respected men. Christine utilizes pagan society's perception of the maiden - a naïve and feeble young woman - to underpin Catherine's strength. Indeed, the following image Christine presents of her heroine is anything but naïve and feeble: "Catherine les harcela de tant d'arguments qu'ils ne surent que répondre à ses questions et s'avouèrent vaincus" (242). Just as the depiction of Saint Christine as young and helpless precedes the image of the earth trembling at her voice, the mockery of Catherine's naiveté precedes her verbal assault of reason and conviction. Instead of denying or ignoring the weakness and passivity associated with her heroine's age, Christine de Pizan presents it as facilitating her authority.

Saint Catherine's physical beauty functions similarly. As I noted previously in the example of Saint Christine, maidenhood was representative of ideal feminine beauty and desirability in addition to symbolizing the intimate connection between God and holy women. Christine de Pizan also employs this tension between eroticism and spirituality to highlight Catherine's significance and activity within her story:

Le tyran Maxence qui convoitait la beauté de la bienheureuse Catherine, lui fit alors une cour assidue pour l'amener à se rendre à ses désirs. Voyant que rien n'y faisait, il en vint aux menaces, puis à la torture...Mais les anges de Notre-Seigneur la visitèrent et la réconfortèrent, et quand au bout de douze jours elle fut ramenée devant l'empereur, elle était encore plus belle et plus fraîche qu'auparavant. (243)

Although Catherine is not depicted as the traditional virgin martyr and holy spouse flowing golden hair and wearing the martyr's crown - the text nevertheless conjures a similar image. Kim M. Phillips asserts that in addition to representing the maiden's privileged relationship to God, the crown or garland signified "victory over death through 
eternal life" (46). I would argue, then, that Catherine's miraculous beauty following her torture and visitation by angels may be read as her metaphorical martyr's crown - her beauty symbolizes her active $e^{9}$ victory over the emperor as her physical death will not stifle the influence of her authority. It is worth noting as well that in this passage Christine de Pizan does not shy away from the objectification of her heroine, rather she once again utilizes the demeaning male gaze to underscore the active identity of her heroine.

As a final example of Christine de Pizan's unique treatment of maidenhood in her Christian heroines, I would like to address Joan of Arc. Up until this point, I have chosen not to include Christine's final heroine in the discussion of the holy couple and hesitated to do so in the current discussion, because at the time the Ditié was composed, Joan of Arc was neither a martyr nor officially regarded as a saint, or even saintly by the general public. In fact, there is evidence to suggest that it was Christine de Pinzan's poem in addition to several treatises praising the accomplishments of the Maid of Orléans, that led to the public's accepting of Joan as the divinely ordained savior of France (Fraioli 81519). Nonetheless, Joan of Arc's age is paramount to Christine de Pizan's formation of her heroine's identity in the Ditié and the author presents Joan as if she were already regarded as saintly, going so far as to predict her future coronation amongst Biblical heroes. It follows, I posit, that Joan of Arc should at least be mentioned in the discussion

\footnotetext{
${ }^{9}$ In the previous section "The Holy Couple" I referenced Karl D. Uitti's chapter "Women Saints, the Vernacular, and History in Early Medieval France" in which he concurs that Saint Catherine plays an active role in her story in addition to perpetuating the Christian faith (256).
} 
at hand, given that Christine de Pizan seems to have already regarded her as a holy maiden.

Like Saint Christine and Saint Catherine, Joan's age is emphasized repeatedly throughout the Ditié and appears to hold a certain spiritual significance for Christine de Pizan. The author not only continuously refers to Joan as the pucelle, pucellette and fillete, all of which indicate her maidenhood, but also states her exact age:

Une fillete de XVI ans

(N'est-ce pas chose fors nature?),

A qui armes ne sont pesans, Ains semble que sa nourriture

Y soit, tant y est fort et dure!

Et devant elle vont fuyant

Les ennemis, ne nul n'y dure.

Elle fait ce, mains yeulx voiant. (lines 273-80)

In what seems to be a pattern in Christine's writing, she juxtaposes language that both explicitly and implicitly implies youth, innocence and female frailty, with a lexicon of authority, action and violence. Moreover, coupled with her use of the diminutive, Christine's declaration that Joan is, in a sense, supernatural owing to her age and innocence, suggests that she intended to align Joan with the celebrated virgin saints of the Christian faith; perhaps she even intended for her readers to make this connection themselves. Whatever the intention, the symbolism of the pucelle is undeniable - a young woman at the peak of female perfection and spiritualism, uniquely positioned to speak and act on behalf of God. While Christine de Pizan does not depict Joan's power as communicable through God as she does in the cases of Saints Catherine and Christine, she presents Joan's maidenhood as indicative of her divine authority as well as a justification for her heroine's active and atypical role as the savior of France. This is not 
to say that Christine's use of the symbolism of Joan's age suggests that she holds as unique a position of active authority as the saintly women of the Cité do; after all, it has been established, and I agree, that Joan occupies a subordinated role in relation to God. Notwithstanding these differences, the fact that Christine de Pizan attributed a similar significance to Joan of Arc's age provides us with important insight into the author's intentions for writing the Ditié, which will make up part of the discussion of my third and final Chapter.

Thus, an examination of Christine de Pizan's Christian heroines provides us with two concrete answers to the questions posed at the outset of this chapter: what effect, if any, does a divine connection have on the agency and activity of both Christian heroes and heroines? Do these figures lose independence and/or authority through their relationship to God? Excluding saints and martyrs, I concur that Kevin Brownlee's assertion that Christian women's heroism is necessarily passive is accurate in that Christine's women are represented as grammatically passive in relation to God or frequently as the instrument - an active object - through which God performs miracles. I posit that we may add two clarifying points to this conclusion: 1) that the heroism of both Christian women and men is passive in respects to God, and 2) that despite this passive position, both Christian heroes and heroines maintain a level of independence and authority over their earthly heroic actions. I demonstrated these points through a discussion of Christine de Pizan's treatment of Joan of Arc and the biblical heroes to whom she compares the Maid of Orléans, in addition to an examination of Giovanni Boccaccio's depiction of Christian male heroism in De Casibus Virorum Illustrium. 
While Joan of Arc is certainly subordinated through her role as God's vessel in several stanzas throughout the Ditié, Christine deliberately distinguishes her heroine from her divine mission, creating a separate, active character. Moreover, the writer's depiction of male heroism in the same poem demonstrates that Joan's passivity is not unique to her sex - Moses, Joshua and Gideon are all, similarly, the vessels of God. The same is true in Boccaccio's writing; while Cicero is an instrument through which God acts, he nevertheless maintains agency over his voice and actions.

My second answer to the question of activity and independence in Christian heroism is unique to women saints and, more specifically, martyred maiden saints. An examination of medieval French hagiography's understanding of gender and women reveals that saintly women and virgin martyrs occupied a unique role in relation to God: that of an indispensable part of the divine couple and God's earthly temple. In the lives of Saints Christine and Catherine, as depicted in the Cité, Christine de Pizan dominates her narration with symbols of, and references to, the privileged relationship between holy maidens and God. Christine also represents Joan of Arc's maidenhood as a symbolic justification for her authority; however, as Joan was not officially regarded as a saint or a martyr until the twentieth century, she should not be viewed as occupying a similarly significant role. Nevertheless, the writer does accord Saint Catherine and Saint Christine a unique position of activity: rather than act through them, God acts on behalf of these women - their authority is uniquely privileged above men's and even communicable through God's. As a result, I assert that in the cases of saintly heroines and virgin martyrs, their heroism is not inherently passive, but inherently active. 


\section{Chapter III}

\section{Reimagining Feminine Identities: Between Practice and Literature}

In the previous two chapters I examined how Christine de Pizan carefully reconstructs traditional female roles and characteristics through language to reimagine the literary notions of passivity and activity. Chapter I focused on Christine's use of the masculine body to describe and justify her female protagonists' action in traditionally male roles, as well as the writer's reversal of literary history's perception of female bodies - virginal and maternal - as weak, vulnerable, submissive and dependent. The following chapter addressed the effect of religion on Christine de Pizan's Christian heroines to further demonstrate how the author uses, rather than rejects, religious and societal views of women and their bodies to establish her heroines' activity within their milieus. I would now like to broaden my discussion to examine how Christine de Pizan writes herself into Le Livre de la cité des dames and Le Ditié de Jehanne d'Arc. It has been thoroughly demonstrated that Christine de Pizan used her character in the CitéChristine-protagonist - to validate her real-life authority as a female author in a maledominated society and literary practice. "Christine is consciously seeking to position herself in the canon as an authoritative representative of 'Truth' based on her gendered experience, her reason and her 'purer' knowledge of the past" (Nowacka 88). The same has been shown in the Ditié; Christine's personal connection to prophecies predicting the Maid's arrival may be interpreted as the final proof, as it were, of Christine de Pizan's authorial agency: "Joan of Arc...authorizes, validates, not only the literary enterprise of the Ditié, but Christine's entire previous literary career, her very identity as auctor, her 
self-created je, Christine" (Brownlee, "Structures of Authority" 150). With this in mind, I aim to demonstrate how we may also understand Christine de Pizan as the 'real-life' embodiment of her work recoding notions of activity, passivity and their associated gendered roles and characteristics. Moreover, I will argue that the Ditié de Jehanne d'Arc marks not only the culmination of Christine's life work, thereby solidifying her authority as a female author, but that Christine's Joan represents an important bridge between literature, practice and history: retroactively completing the Cité's call to "toutes les femmes honorable - celles de jadis, celles d'aujourd'hui et celles de demain" and demonstrating the reciprocity between fiction and reality (275).

\section{Creating the Space for a Dynamic Feminine Identity}

Let us begin by revisiting the opening of the Cité in which Christine-protagonist expresses her immense dismay at being born female and thus, according to every text of authority, philosophy and religion, a monster of nature - an abominable creation:

Hélas! mon Dieu! pourquoi ne pas m'avoir fait naître mâle afin que mes inclinations aillent à ton service, que je ne me trompe en rien et que j'aie cette grande perfection que tous les hommes disent avoir! ... Je me répandais ainsi en lamentations envers Dieu, disant cela et encore davantage, tristement affligée, car en ma folie je me désespérais que Dieu m'ait fait naître dans un corps féminin. (37-8)

While this statement appears to fly in the face of the proto-feminist tone that the Cité conveys, the sentiment of wishing to be born male, which, it is worth noting, is not unique to the Cité,${ }^{10}$ is actually aligned with the text's principles. Christine-protagonist expresses her disdain for her sex because of society's perception of women as imperfect

\footnotetext{
${ }^{10}$ Maureen Quilligan observes that in Christine de Pizan's Mutacion de Fortune, "Christine had said that Fortune changed her into a man so she could take the helm of her foundering ship..." (“Allegory and the Textual Body" 231).
} 
and inferior. Therefore, it is not necessarily her female body that Christine regrets, but the status of the female body in fifteenth-century French society. Monique Wittig contends that 'man' and 'woman' are "political categories and not natural givens" (13-14). Furthermore, the category of 'woman' only exists in its relationship to 'man': "For what makes a woman is a specific social relation to a man, a relation that we have previously called servitude, a relation which implies personal and physical obligation as well as economic obligation..." (20). If we read Christine-protagonist's despair at being born a woman in this context, we may assume that she does not wish to be a man, but wishes to hold the same social, political and economic status as men; and this desire repeatedly manifests itself through the Cité's heroines. Moreover, given that Christine de Pizan depicted her character as longing to escape the constraints of her social category across multiple texts, I posit that it is also appropriate to draw a parallel between Christineprotagonist and Christine-author, and that we may assume that Christine's character reflects the author's personal struggle with her position in society. Therefore, we may read the Cité as Christine de Pizan's attempt to resolve her own inner conflict, as well as establish a literary genealogy that redefines the category of 'woman.' An examination of the events of the author's life demonstrates this well.

The noble-born daughter of Thomas de Pizan, an Italian savant who served at Charles V's court and eventually moved his young family to Paris in 1368, Christine enjoyed a privileged childhood in the presence of intellectuals and nobility. Her father took it upon himself to ensure that Christine received a similar education to her two brothers, thus setting her apart from the majority of the other young girls at court early on 
in her life (Roux 27-8, 52). However, the privilege of knowledge came at a price: her mother discouraged Christine's scholarly formation, and despite being well-educated, according to society's rules, Christine could never be a true savant. Simone Roux aptly summarizes the tension this would have caused in Christine's life and aspirations:

Mais quelle que soit l'ouverture d'esprit de son père, elle n'allait pas jusqu'à lui préparer un avenir de savant, car, rappelons-le, qui dit savant dit clerc lettré, et qui dit clerc dit masculin. Il n'y a que deux Chemins possible dans la vie d'une jeune fille, le mariage ou le couvent. Apparemment, Christine n'avait pas le profil d'une religieuse... (52)

So, from an early age, Christine would have been caught between the masculine and feminine worlds, never fully accepting her status as a woman, yet never able to access the intellectual, social and economic opportunities that men enjoyed. Christine was eventually married to Étienne Castel - a man of science and philosophy who served as a notary at the court of Charles VI - and by all accounts, including Christine's, the marriage was full of love and mutual respect. However, Étienne's untimely death plunged Christine, now the mother of three children, into depression and destitution upon discovering that she would receive none of her husband's wealth (Roux 64-76). Christine, finding herself alone with her children and aging mother, was once more faced with two choices: remarriage or the convent. Christine chose neither. Instead, having maintained her relationships with Étienne's patrons and colleagues at the court of Charles VI, Christine was able to acquire work as a scribe, eventually gaining the patronage of royals such as Isabeau de Bavière, marking the beginning of her career as the first professional female author (Roux 87-95). Consequently, Christine de Pizan remained torn, as it were, between two roles: that of a mother - a traditional and appropriate feminine role which 
she appears to have cherished deeply - and that of the provider for her family - a role almost exclusively occupied by men. In fact, Christine faced a surprisingly modern challenge: being both a mother and a professional woman in a society constructed in such a way that women were, for the most part, entirely financially dependent on their husbands or fathers. It follows then, that the discord Christine felt as child must have been exacerbated by her circumstances following her husband's death, pushing the author to question why the space did not exist for women to be both independent ('masculine' and active) and maternal or traditionally feminine.

When we view the Cité from the context of its author's upbringing and circumstances as an adult, we see to what extent many of Christine's heroines reflect her own dynamic identity. 'C' est la femme seule, veuve, chargée de famille, résolvant avec courage les problems matériels, qui est la représentation la plus fréquente que Christine choisit de donner d'elle" (Roux 169). Christine embodies the passive and active roles she aims to validate and justify through her exemplary women. Of particular interest to the discussion at hand are the roles of the mother and the warrior, perhaps the epitomes of the passive $^{11}$ and the active respectively, that Christine de Pizan frequently depicts as coexisting in the heroines of the Cité.

The image of the mother in the Cité, as we have already seen, is a conflicted one. Although Christine's own mother served as an ever-present obstacle to her scholarly pursuits, Simone Roux notes that Christine had the utmost respect for her mother's

\footnotetext{
${ }^{11}$ In Chapter I, I discussed Julia Kristeva's theories of motherhood and the inherent dependency of the mother on the father (304). While acts of mothering and nurturing are, in fact, active, motherhood is nevertheless viewed to be a role of vulnerability and dependency, thereby rendering the role passive.
} 
nurturing role in her life (57). The tension created by these two conflicting opinions of motherhood is aptly depicted in the opening of the Cité, in which Christine-protagonist's mother calls her away from her studies to come eat. Maureen Quilligan postulates that this scene is intended to at once signal a major influence of the Cité-Christine's relationship with her mother - and provoke the reader to "continually keep in mind the relationship between the two activities - feeding and writing" ("Rewriting the Body" 238). I would extrapolate upon this to include Christine de Pizan's identity as a mother herself as an important catalyst for the image of mothers in the Cité. While the two activities may have been opposed in the author's relationship with her mother, they were not so in her own experience with motherhood, and thereby, the inherent masculine versus feminine and implied superior versus inferior contrast between the two is brought into question.

It is this traditional opposition that Christine repeatedly addresses through the Cité's heroines. The author pointedly chooses to reconstruct this opposition, presenting the feminine as masculine, the masculine and feminine in harmony, as well as the passive as active or the two notions as reciprocal. My examination of the Sabines and the anonymous woman who nurses her mother in prison demonstrated this reinterpretation of traditionally gendered language and social roles: the former, who transition from the passive victims of rivalry into the active saviors of their people by using their infants and their own nursing and pregnant bodies as a barrier between the armies of their fathers and husbands; the latter, who actively uses her perceived weakness and helplessness to visit her imprisoned mother and nurse her back to health, thus using her body as a tool of 
rebellion. I contend that these images of motherhood distinctly reflect Christine de Pizan's complex comprehension of her own role as a mother. True, the author never took up arms to fight or used her body as such a literal instrument of rebellion - her rebellion was her writing; and she wrote as both a mother and a woman fighting for space in a culture and language that continuously tried to diminish and subjugate her identity.

To further illustrate the similarities between Christine and her atypical heroines, I would like to draw upon her account of the Amazon women in Part I of the Cité:

Il est, proche de l'Europe, une terre jouxtant la grande mer océane qui entoure le monde: on l'appelle la Scythie ou terre des Scythes. Il advent un jour que les ravages de la guerre privèrent cette terre de tous les nobles hommes de la region. Les femmes du pays, voyant qu'elles avaient toutes perdu mari, frères et parents... décidèrent que désormais ells gouverneraient le royaume sans tutelle masculine et promulguèrent une loi interdisant aux hommes l'accès du territoire. (71)

Whereas Boccaccio's depiction of the origins of the Amazonian empire paints a gruesome image of murder and betrayal on the part of the Amazons, who then pervert themselves by cutting off their left breasts so that they may become more efficient warriors, Christine's interpretation alters the narrative in a positive and personal way (Dufresne 121). The account of the accomplishments and virtues of various Amazon women continues, making up a large portion of Part I of the Cité, and demonstrating that Christine, unlike her contemporary, revered these women as symbols of feminine power and dynamism. Moreover, their origins in the Cité are eerily reminiscent of their author's: having lost their husbands in a tragic and untimely fashion, the Amazon women found themselves poised to either lose their empire entirely or take up the mantle and assume the roles of both mothers and fierce rulers. This authorial choice to change their origins, 
while innocuous in that it fits logically into the overall aim of the Cité - to establish a feminine literary genealogy - also reflects the extent to which Christine chose to write herself into her heroines. Just as the Amazons became rulers and warriors by both necessity and choice, Christine became a professional author, at first by necessity refusing to remarry, yet needing to feed three generations in her household - perhaps later coming to realize that she was just as capable of the profession as her male counterparts. To add to this, the Amazons are depicted in such a manner that the role of the mother and the warrior/ruler seem to exist in perfect harmony. In fact, it is through motherhood that Hippolyta, a young Amazonian woman accomplished in warfare and without equal in courage and virtue, brings peace to the war between her people and the Greeks:

C'est ainsi que Thésée emmena Hippolyte, dont il eut par la suite un fils qui porta le même nom. Celui-ci devint un chevalier célèbre et accompli. Quand les Grecs apprirent que la paix avait été signée avec les Amazones, leur joie ne connut plus de bornes, car il n'y avait rien, en vérité, qu'ils redoutassent autant. (77)

Hyppolyta does not lose her authority because she marries a Greek and bears his child; on the contrary, her abilities as a warrior (and those of her people) remain just as impressive and her role as a mother only further solidifies her power. We see such a dynamic identity - both passive and active, masculine and feminine - time and again in the Cité; it cannot be coincidence that Christine de Pizan identified as such as well.

It also bears mentioning the powerful mise en abyme that is created by Christine modeling her heroines after her own complex identity - Christine is active through her writing of active and dynamic women, who, the text suggests, were intended to clear the 
pathway for future active and dynamic women. We may also include in this discussion the validating relationship between the act of writing, the authorial voice, and the voices of Christine's heroines. The implications of this relationship have been thoroughly examined in previous studies of the Cité, ${ }^{12}$ so I will only summarize them here, but this should not detract from the significance of the connection. Christine's writing validates her authorial voice through the voices of her heroines as well as her character in the Cité (Brownlee, "Structures of Authority" 133-34). What's more, the book itself is intended to validate the voices and writing of future women. When we consider the historical context in which Christine de Pizan was writing, the reciprocity between the author and her subjects appears to be all the more poignant. Cristina Malcolmson observes that while women writers were extremely rare during the fifteenth century, Christine de Pizan was not entirely unique in this right. Notwithstanding, Malcolmson contends that the majority of these writers were not "free agents"; the rules and circumstances under which they were allowed to write meant that their work necessarily perpetuated the marginalization of women in the intellectual and clerkly spheres (16). As we have already seen, Christine de Pizan was able - through necessity and her upbringing - to practice her craft under markedly different circumstances. By gaining respect as an author through her work at court and thus becoming financially independent, Christine was uniquely positioned to write for herself and even disseminate her thoughts to a broad audience. Therefore, not

\footnotetext{
${ }^{12}$ For a thorough examination of the relationship between writing, the female voice and the body (primarily the tongue) in Christine's texts, refer to Kevin Brownlee's chapter "Structures of Authority in Christine de Pizan's Ditié de Jehanne d'Arc" in Discourses of Authority in Medieval and Renaissance Literature (131-50). Refer as well to Maureen Quilligan's chapter "Rewriting the Body: The Politics of Martyrdom" in her book The Allegory of Female Authority: Christine de Pizan's Cité des Dames (189-245).
} 
only was Christine using her writing to validate her authority as a distinctly feminine author and creating the space for others to follow, she was also recoding what it meant to be a 'woman writer' - no longer beholden to the parameters under which men deemed it permissible for women to write.

What I have attempted to demonstrate through this discussion is that, while highly allegorical, Le Livre de la cité des dames is grounded in a very real model of the dynamic and atypical characters it celebrates - Christine de Pizan. The author writes her heroines in such a way that reflects her own experiences with her gender, her female body, her scholarly pursuits and her role as a mother. Fifteenth-century European society and literature dictated strict gender roles, behaviors and characteristics that remanded women to submissive, dependent and passive positions while men assumed the positions of authority, independence and financial power. By both nature and necessity, Christine de Pizan did not fulfill the roles expected of her as a woman; however, she was also unable to surpass the limits of her body and belong to the ranks of men. Cherishing her role in life as both a mother and a savant, Christine sought to create a literary space in which she and other virtuous, noble and atypical women could exist.

The idea that Christine de Pizan embodied her work in the Cité touches upon the intersection of practice and/or history and literature - that it is possible for one to either influence or inspire the other. As I, as well as scholars like Maureen Quilligan, Kevin Brownlee and Keiko Nowacka have observed, there are multiple personal connections between Christine de Pizan, Christine-protagonist and many of the historical and/or legendary women her text honors, each providing insight into the intentions and 
influences of the author and her works. While it is always difficult to discern definite causal effects between literature and history and vice versa, examining this relationship remains an interesting and useful exercise. As we have seen, in the context of Christine de Pizan's own life, examining her history and circumstances provides us with a possible origin story of sorts for the author's reimagination of passive and active roles in literature. In the following section, I would like to explore the Ditié de Jehanne d'Arc within the context of the Cité and how we may understand Joan of Arc, both fictional and historical, as representative of the reciprocal relationship between literature and historical reality. I will then discuss to what extent this grounding of Christine's fictional work may or may not be observed in later examples of historical dynamic women and European society.

\section{Le Livre de la cité des dames and Le Ditié de Jehanne d'Arc: Beyond Fiction?}

While I am certainly not the first to remark the serendipitous arrival of Joan of Arc during the lifetime of an author who spent much of her career fighting for the defense of women eerily similar to the Maid of Orléans, little research exists beyond postulating the potentially causal connection between Christine de Pizan and Joan of Arc. This is most likely due to the uncertainty inherent in any such conclusion. Nevertheless, this ultimately unconfirmable relationship between Christine de Pizan and her final heroine remains an area of great intrigue for many who study Christine and her proto-feminist works, myself included. While we may never have any definite answers, I believe that this question has merit beyond whether or not there is a concrete causal correlation between Christine de Pizan's texts and the arrival of Joan of Arc, as it opens up our 
discussion to the potential practicality of the author's work in the Cité as well as in the Dité from both a literary and sociopolitical standpoint - was Christine able to affect any change in the way literature portrayed women or the roles authors accorded to female characters? Was she able to influence society's views of women, particularly those deemed atypical? We have already seen how Christine fashioned her heroines after her own dynamic and atypical identity - creating the literary space in which she could reinterpret notions of passivity, activity and their associated gender roles and biases to reflect what she believed to be the truth. Now, I would like to turn our discussion outward to examine what, if any, effects can be identified between Christine's work and the literary as well as social spheres in which her texts were disseminated. Literary history tends to exclude Christine de Pizan from those authors who would be considered significant and influential; but, as we will see, although her work did not revolutionize or drastically impact the social, political or literary scenes in her lifetime, there is indeed evidence of Christine's influence in the years following her death. Moreover, the historical figure of Joan of Arc represents a significant confirmation of Christine's arguments and validation of the space she created through the Cité. Although Christine appears to have fashioned her character of Joan in the Ditié to conclude the Cité 's call to women past, present and future, her account of the Maid's actions remain pointedly accurate ${ }^{13}$ Therefore, the aim of this section will be to demonstrate how Christine de

\footnotetext{
${ }^{13}$ Although Christine de Pizan structured the character of Joan of Arc in the Ditié to reflect some of her more illustrious women of the Cité, Stecopoulis and Uitti confirm that her account of Joan's actions, abilities, and self-declared identity as a divinely ordained remains accurate (58).
} 
Pizan's efforts to recode gendered connotations behind passive and active language in literature can, in fact, be seen in historical practice.

As I mentioned above, the image of Joan that Christine presents to her audience in the Ditie is a mix of both historical reality and artistic license - Joan appears to embody at once the Amazonians, Ceres, Minerva and Medea of the Cité, while her character remains very much grounded in the present and the reality of her actions aiding in Charles VII's fight for the throne (Stecopoulis and Uitti 53-5; Quilligan, "The Practice of History" 280). This crossover of history and legend is common in Christine de Pizan's writing and is undoubtedly indicative of the author's intended use of Joan as a final validation of her own authority and arguments. Furthermore, as scholars such as Maureen Quilligan and Kevin Brownlee have demonstrated, Christine's reference to sibylline prophecy in the Ditié is almost certainly a direct reference to the sibyls of the Cité. "Christine's career-long investment in the sibylline prophecy, from the early text of the Epistre Othéa to this last poem, conformed to a widespread belief in fifteenth-century France in prophecy and sorcery...predilections Jehanne and Christine shared with their king” (Quilligan, “The Practice of History” 278). Quilligan goes on to say, and I concur, that the use of prophecy in the Ditié was at once meant to directly recall Christine's prior works and to appeal to a King and a court that already believed numerous prophecies predicting the advent of France's savior (279). Therefore, we may already see how the Ditié was actually intended to bridge the gap between literature and practice. Of course, Christine's optimistic predictions for Joan of Arc's radiant future were incorrect. Joan did not go on to be successful and claim glory in the Holy Land alongside Charles VII. As we 
know, Joan was burnt at the stake in 1431, two years after Christine penned Le Ditie de Jehanne d'Arc; put to death as a heretic and a witch for the same reasons she was at one point lauded and honored as the heroine who would bring victory to Charles VII and to France. Although, rather than undermine the prophetic connection between the Ditie and the Cité, scholars agree that Joan's unfortunate fate merely provides insight into the reality of society's response to women such as Joan. "Christine thus may be said to have prophesied more compellingly in the Cité's martyrology what actually happens to the kind of women she celebrated within it, than she did in the Merlinic mix of Jerusalembound prophecy she actually gives in the Ditié" (Quilligan, "The Practice of History" 282).

It is here that I would like to draw attention to my own findings concerning Joan of Arc discussed extensively in Chapter II. Quilligan and other scholars tend to focus on the prophetic connection between the Ditié and the Cité in addition to Joan's similarities to the Amazon women, Minerva, Medea, and Ceres among others, when comparing the two works and/or providing evidence as to why Joan should be perceived as the culmination of her life's work, “a living, exhilarating embodiment of all she had been advocating: female virtue, intelligence, strength, and governance" (Barr 4-5). I in no way intend to question or downplay the immense importance of these findings and similarities; however, I posit that when we read the Ditié in the context of the Cité, it is possible to read Christine's portrayal of Joan of Arc not only as an embodiment of the more prominent women warriors and rulers of the Cité, but as a kind of preparation for Joan to join the martyred virgin saints of Part III of the book - to complete the fictional 
city of ladies. Although Christine frequently mentions Joan's miraculous strength and military prowess - reminiscent of Minerva and the Amazons - she chooses not to portray the Maid of Orléans as masculine, nor does she reference Joan's cross-dressing, which was often used against Joan in attempts at her defamation. Given that Christine frequently used masculine language and imagery to refer to her warring heroines of the Cité, it is decidedly unlikely that Christine chose to omit this detail because she herself disapproved of Joan's masculine garb and gender performance. Rather, there are two probable explanations: Christine wanted to make her heroine more appealing to her misogynistic audience, and she believed that Joan belonged to different group of heroines - the holy maidens.

Despite Christine's astute prediction that Joan would become a historically significant character, we clearly cannot assume that the author knew that Joan would become a martyr of the Christian faith, nor that she would be canonized centuries later in 1920. However, I argue that when we examine Christine de Pizan's portrayal of Joan in the Ditié, we cannot ignore the similarities between Joan and the likes of St. Christine and St. Catherine. In Chapter II, I detailed the stanzas in which Christine appears to make deliberate references to imagery often associated with the holy maiden and the martyred virgin. Of note are the instances in which Christine emphasizes Joan's identity as maiden - pucellette, pucelle, fillette - as well as her reference to Joan's future coronation: “Ceste doit porter la couronne" (line 346). Firstly, Christine's insistence on Joan's age and sex strongly recalls her narration of Saints Catherine and Christine in the Cité, in which she frequently refers to the innocence, physical beauty, naiveté and youth of the two girls. 
While she does not use the diminutive in these chapters as she does in the Ditié, Christine emphasizes their maidenhood by referring to St. Catherine as "une toute jeune fille" and St. Christine as a "tendre jeune fille" $(242,259)$. As we have seen, during the fifteenth century and later Middle Ages in general, the period of maidenhood was highly significant in society as well as in the Christian faith, as it was during this transitional period in a girl's development that she was closest and most receptive to God, and was even viewed as his earthly temple. Given that the Ditié is heavily laden with both references to Joan as the divinely ordained savior of France and Joan's status as a maiden, it follows that Christine's intent most likely was to elevate her heroine's significance to that of the virgin saints of her fictional city. An alternate interpretation of Christine's declaration that Joan should 'wear the crown' could be that of the martyr's crown - motifs also present in both St. Catherine's and St. Christine's stories. While it seems unlikely to me that Christine would have written such a direct symbol of martyrdom into a poem prophesizing the glorious future of Joan, having used such imagery many times before, she would have been aware of the connection between maidenhood and crowns (often of stars or flowers). Furthermore, when Christine turns her discourse to the French people who question the validity of the maiden, she admonishes them using language that appears to mirror that of her narration of St. Christine's life:

N'appercevez-vous, gent aveugle, Que Dieu a icy la main mise? Et qui ne le voit est bien bugle, Car comment seroit en tel guise Ceste Pucelle ça tramise Qui tous mors vous fait jus abatre? 
-- Ne force (n') avez qui souffise!

Voulez-vous contre Dieu combattre? (Le Ditié, lines 369-76)

There are two points of connection in this stanza: that the French are blind if they do not see the divine intervention behind Joan's arrival, and that to refuse to accept her would be to fight against God. Granted, in St. Christine's story the third judge is literally blinded by the saint's severed tongue; however, both the French and the judge are blind because they refuse to heed the messages of holy maidens. Sight and blindness were and are highly significant in the Christian faith (although their meanings have evolved over time) and in the Middle Ages took on a unique symbolism in relation to saints: "The first understanding of blindness was as a physical manifestation of divine punishment. The ability to inflict blindness upon the impious underlined the saints' special status as God's agents..." (Hawkins 149). Finally, as evidenced by the accounts of Saints Catherine and Christine in the Cité, Christine de Pizan appears to ascribe to her century's belief that maidens could become God's earthly temple - to refuse their power is to refuse God's, to inflict violence upon them is to threaten violence upon God. That Christine and others who wrote in Joan's honor portrayed her as God's divine daughter is, of course, not a novel idea, but it is important to understand the Ditié within the larger context of its literary history and notably Le Livre de la cité des dames. When we read Christine de Pizan's work in this manner, we are able to see to what extent her writing was inspired by and interacted with the political, cultural and religious atmospheres of her time. At the risk of my analysis appearing too much of an extrapolation, I would also like to point out that in discussing how Christine de Pizan would have responded to the knowledge of Joan's execution, Maureen Quilligan concedes that it is possible that Joan's fate would 
not have discouraged Christine from her prophecy: "There was, in addition, an option for Jehanne's triumph in the future, one Christine would have hoped for her even at the stake. In the twentieth century history has finally exercised that option - Jehanne was canonized a martyr saint in 1920" (“The Practice of History” 282). I would propose, then, that while any retrospective conclusion should be viewed with a certain level of skepticism, Christine's language in the Ditié connecting Joan to the martyrology of the Cité cannot and should not be so quickly discounted.

Perhaps the most important take-away from these connections is not whether Christine intended for Joan to fit in with the warring women or the holy maidens and virgin martyrs of the Cité, but how this discussion demonstrates the transferal of ideas, morals and practices between literature and society. I have shown how Christine grounded her fictional city of ladies, both historical and mythical, in a very real model of the identities she portrays and defends therein - herself - but, I contend that her connection to reality does not end there. Joan of Arc, regardless of whether or not her success was in any way contingent on Christine's influence in the French court as a woman writer prior to her arrival, represents a second model of Christine's reimagined feminine identities whom the political and erudite spheres could not dismiss as merely fictional and/or allegorical. Whether by coincidence or design, the historical figure of Joan of Arc embodies the concept developed throughout the Cité and one that I identified at the outset of this thesis: the heroine who is both passive and active. Joan's status as France's heroine was uniquely dependent not only on her occupying an active role traditionally reserved for men, but on her identity as a Christian heroine - passive under 
God. Therefore, Joan may certainly be seen as the serendipitous culmination of Christine de Pizan's life-long fight for women, but also, I would argue, as a figure who grounds the allegories and mythical stories told in the Cité in France's historical reality. Christine de Pizan adapted the 'real' Joan to serve as a current, living, and undeniably exceptional example of the Cité 's heroines, thereby transferring her arguments from the fictional to the factual.

While history has shown that in the centuries following Christine's death, no substantial changes were made to the scope of women's opportunities in the professional and social spheres uniquely because of Christine de Pizan's work, there is, nonetheless, evidence of its perpetuation in both the literary and political spheres. Notably, in 1521 at the English court, a debate arose between Henry VIII and Catherine of Aragon, concerning their daughter's legitimacy as successor to the throne, around the same time La Cité des dames was translated into English, albeit frequently anonymously or published under a different name, and made its way into the royal libraries. Cristina Malcolmson explains that Catherine, wanting to educate her daughter in preparation for succession, invited the humanist Juan Luis Vives to court as Mary's tutor (20). Vives, author of De Institutione Christianae Feminae, an instructional manual for the education of women, likely included Christine de Pizan's work in the Princesses' education: “The publication of The Boke of the Cyte of Ladyes in October was the first in a series that promoted the education of women, and indirectly, the legitimacy of female monarchs" (20). Moreover, Malcolmson goes on to say that the Cité may have even been part of the 
debate at the English court, making up part of the defense for Mary's claim to her father's throne:

Within the court, the concept of a "city of ladies" would have been a powerful method to counteract arguments against female sovereignty and support Catherine's interests. Defenders of Mary may have appealed to arguments in favor of women rulers in the French manuscript of Cité des dames, and to the printed translation. (20)

This is not to suggest that the Cité was wholly instrumental in defending Mary (who would eventually take over the monarchy and rule as Mary I of England) as I do not believe that to be the case. Instead, I wish to draw attention to the possibility that readers of Christine de Pizan's Cité did not view the text as purely allegorical if its contents were an acceptable line of argumentation for the legitimacy of women rulers. In fact, given both Catherine's and Mary's privileged positions as women poised before the possibility of gaining great power and agency, yet very much dependent on their familial link to Henry VIII that accorded them this privilege, it seems likely that both women would have found commonalities with Christine's heroines. This assumption is strengthened by the discovery that in both the English court of Henry VIII and the Scottish court of King James V, tapestries depicting "the Citie of Ladies" were quite popular and hung in many of the royals' personal chambers (Malcomson 17-8). Whether or not the royal women of the English court were fully aware of the literary inspiration behind the tapestries' imagery is unclear; but, their mere presence demonstrates that the ideas resonated on some level with these women. As Cristina Malcomsom's extensive research has indicated, the vision depicted by these tapestries, and embraced by several royal women, 
suggests "that a female ruler can fulfill the duties of the office, and that she will need active defense against misogynist detractors" (21).

It is worth noting in addition that Mary's tutor, Vives, although a humanist who agreed with several portions of Christine's Cité, believed strongly that women should not stray from their traditional roles of passivity within society:

The Instruction certainly advocates the education of women but only for the edification of the individual, as women have no role to play outside the home. The author Vives asks rhetorically, "you women that wyll medle with comen matters of realms and cities...Wene you it was for nothing / that wyse men for bad you rule and gouernance of co[u]ntries" $(\mathrm{h} 2 \mathrm{v})$, and, in case any of his readers should nod their heads at this point, he promptly explains the rationale of those wise men. Women are temperamentally unsuited to public life because in such a situation they are disposed to become proud, headstrong, and combative. (Rooks 85)

So, although Vives served as Mary’s tutor, he may not have personally approved of her and Catherine vying for the throne and denying Henry's illegitimate but male heir's claim to the monarchy. It is admittedly unknown to what extent, if at all, Vives would have been able to express his personal convictions while Mary was under his tutelage. Nevertheless, I posit that given Vive's disapproval of women in active, ruling positions and the general popularity of the idea of a city of ladies within the English court at the time, it seems more likely that the tapestries depicting the "Citie of Ladies" and manuscripts of the Cité would have been the sources of validation for women such as Catherine and Mary, exactly as Christine de Pizan had intended - a literary history to legitimize dynamic, atypical women. After all, Catherine and Mary's story is not wholly unlike those of the Cité, albeit far less fantastic and awe-inspiring. Theirs is one of a mother fighting for her daughter to be accorded the same inheritance she would have 
received without question, had she been born male; and Catherine did so in the English court, wherein "action by women implied the emasculation of men" (Warren 432).

There were undoubtedly many other factors at play within the debate surrounding Mary's right to rule, most importantly perhaps, the issue of male primogeniture, which dictated the rules of succession to the British throne and privileged male heirs, not unlike the Salic Law in France. Although male primogeniture follows birth order and does not exclude women entirely from the throne as Salic Law does, both systems are considered to be forms of "agnatic succession" meaning that female succession is discouraged, if not prohibited (Corcos 1603-04). Notwithstanding the complex politics at play within this debate, I would argue that the possibility of a connection between Christine de Pizan, Catherine of Aragon and Mary still provides us with some insight into the practicality of the Cité and Christine's passive heroines. Like the historical figure of Joan of Arc, Catherine and Mary ground the principles presented by the Cité in reality, representing reciprocity between fiction and history. They are not nearly as exceptional as the women who make up the fictional city; but their lives serve as very real examples of the kind of identity and feminine roles Christine wanted to create a space for - more multifaceted and active, yet no less 'womanly.' While the author's efforts to recode feminine roles in literature failed to spark any drastic political or social change, perhaps they could have provided history's atypical women with an argument in support of their validity.

Ultimately, there is no way of definitively proving the extent of Christine's influence at the English court; and this is not the goal of my study. What I have aimed to draw attention to is the complex concept of female dynamism the Cité presented to its 
late medieval readers, that did not exist within a vacuum. Like many writers, Christine de Pizan saw a gap in literary representation that was contributing to what she perceived as the unjust marginalization and mistreatment of women and took it upon herself to be the change she wished to see. It is common to label Christine de Pizan as a writer ahead of her time; one who envisioned gendered roles and identities in a strikingly modern manner. Without a doubt, her arguments for the equal treatment of women were revolutionary for her century; however, perhaps the identity she wished to validate was not as novel as we assume. As I have demonstrated, Christine's work, although highly allegorical, is first and foremost firmly grounded in the author's own identity, but the connections to historical reality do not end with her. The notion of the passive heroine that Christine sought to validate through her writing, did not exist purely in literature and could have held a very practical, if only humbler, significance for Christine's readers. 


\section{Conclusion}

The heroic identities of the women of Le Livre de la cité des dames studied in this analysis, in addition to that of Joan of Arc as she is depicted in Le Ditié de Jehanne d'Arc, can be characterized by their unique synthesis of passivity and activity. As in society, medieval literary tradition relegated its female characters nearly exclusively to positions of grammatical and figurative passivity within their stories - objectified for their beauty and bodies, diminished by their perceived weakness and naivety, merely the recipients of the text's action. Roles of authority and activity were reserved for men and the characteristics the male body represented - chivalry, courage and strength. Christine de Pizan's writing breaks with this tradition by presenting her readers with a dynamic, complex heroine; one whose identity at once validates women in active, often 'masculine' roles - capable of affecting change in their stories and possessing bodily agency - and reinterprets the passive, traditionally feminine roles that literature and society used to limit and oppress women. Christine-author does not seek to disrupt tradition by writing its antithesis; rather, she seeks to recode what is deemed exclusively masculine or feminine, passive or active.

The conclusion that Christine de Pizan upends misogynistic tradition through her writing, in and of itself is not a novel discovery; the writer has long been praised by contemporary literary scholars for her proto-feminist work that presents a strikingly modern interpretation of gender and women's roles in society. However, previous discourse addressing the subject of heroines and atypical women in Christine de Pizan's texts - particularly in the Cité - has for the most part, examined the notions of passivity 
and activity separately. This treatment of grammatical passivity, activity, and their associated gender roles and characteristics as clearly distinct from one another has, as a result, prompted some debate over Christine's more ambiguous figures. Such is the case with Joan of Arc; scholars have frequently questioned how Joan should be classified, their conclusions often attempting to demonstrate her definitive passivity or activity, resulting in a lack of consensus in research. What this debate fails to acknowledge is a distinct pattern in Christine's writing that reveals itself when we study the Ditié's Joan of Arc in the context of the text its author intended for Joan to complete - Le Livre de la cité des dames. When we examine the Ditié and the Cité together, it becomes evident that Christine did not intend for her illustrious women to be either passive or active, but both. Examined in isolation, the frequent alteration between passive and active language, emphasis on her protagonists' independence, authority and submissiveness, perceived helplessness and/or naivety can appear to be mere coincidence, unique to the tale at hand, or perhaps even indicative of the author's own internalized prejudices against her own sex. I do not believe any of these conclusions to be sufficient.

In the present study, I have aimed to demonstrate that the synthesis of passive and active language, roles and characteristics in Joan of Arc and a number of the women of the Cité is in fact, a deliberate authorial choice on the part of Christine de Pizan. We are not intended to view these women as spectacular and powerful uniquely because they defy female gender norms; on the contrary, we are intended to perceive these women as heroic in their entirety, a synthesis of the passive, the active, the masculine and the feminine. Through examining Christine's accounts of her protagonists' suffering and 
achievements, I have been able to identify what I have labeled the passive heroine; an identity Christine creates through her careful use of language, descriptions of the female body and religious symbolism.

Perhaps the most common defining feature of this identity, one that can be found in each of the women studied in this thesis, is the demonstration of activity and independent authority within a position of passivity. That is to say, the character does not fully break from a subordinated role, as one would expect from a proto-feminist account of a heroine; instead, she will often use her subordinated role - whether it be manifested in her physicality, age, social position, or dependence on male authority - to establish her agency. We can see this tactic clearly in the tales of Queen Hypsicratea, the Sabine women, the woman who nurses her mother in prison, Queen Zenobia, as well as Minerva. In each of these cases, characteristics and roles that would most likely, in traditional literary practice, be used to support or define the characters' passivity and/or oppression, instead facilitate their activity. Take the Sabine women for example, whose identities as mothers and wives are necessarily dependent on their husbands, who are also their captors. Yet they use this to their advantage; they take a significantly active stand by threatening to end male descendance through violent self-sacrifice. Similarly, in the case of Saint Catherine, whom Christine elevates through the religious significance of the holy couple, the author chooses to portray the overt sexualization and objectification of the young martyr by the pagan King. Saint Catherine's physical beauty is at once a characteristic used to objectify her and symbolize a privileged position that accords the maiden an authority far greater than that of any man. 
This display of agency within a subordinated position and the use of passivity as a facilitator to authority and activity is emblematic of Christine de Pizan's own identity that of a mother and professional writer who chose to make her own way both because, and despite of, a system that socially and financially disadvantaged women. So, although the Cité is an allegorical, fictional work of literature that embellishes and even rewrites portions of its historical women's lives, in addition to including legendary and mythical women among its ranks, its origins are far more humble and real. The type of feminine identity Christine defends and attempts to validate through the text did exist, in the author herself, and rather serendipitously in Christine's final heroine - Joan of Arc. Although she adapted the Maid of Orléans to fit into her fictional city, Christine's account of Joan remains, for the most part, historically accurate - she was the living embodiment of Christine's passive heroine.

While Joan is an exceptional example, given that she represented quite literally the type of miraculous woman depicted in the Cité, the women who would have found validation in the Cité's chapters were, more than likely, more similar to its author privileged, perhaps noble or royal, yet atypical or unable to fit cleanly into whatever limiting role they were assigned. Historical evidence points to Christine de Pizan's albeit most likely anonymous influence at the court of Henry VIII, where translated manuscripts of the Cité were kept in the royal libraries and tapestries depicting scenes from the text hung in several of the royal ladies' private chambers. Further historical accounts suggest that the principles laid forth in the text in addition to the inspiration of the tapestries, likely served as defending arguments in Catherine of Argon's defense in 
favor of her daughter's inheritance of the English throne. While I am unable to draw any definite conclusions to this end, I feel that these connections do speak strongly to the historical reality of the complex feminine identity Christine validated through her work as well as to the importance of representation in literature. Returning briefly to the notion of mos actisans - the fifteenth-century belief that the written word held the power of a deed - regardless of the actual extent of Christine de Pizan's influence on historical reality, I would argue that Christine clearly believed her words were capable of producing change and intended to not only provide women with an empowering literary genealogy, but perhaps to improve women's status in medieval society as well. Nevertheless, I recognize that this section of my study merits further analysis and would benefit from a more careful and detailed investigation into the perpetuation of the Cité's dynamic feminine identity both in practice and in literature. Is there evidence of other historical figures, like Catherine of Aragon and Mary, having read and identified with Christine's texts? What influence did Christine have on later proto-feminist writers' construction of female protagonists?

This brings me to my final thoughts concerning the present study and its value in the vast practice that is literary research and critical analysis. I, and many others, sometimes ponder the reasons for which we (readers and scholars of early literature) continue to analyze, reinterpret and search for meaning in texts written, in this case, nearly six centuries ago. What use does this exercise serve? Is there really anything new we may learn, and if so, how would it apply to twenty-first century society, literature or politics? 
To answer these questions, I would first say that what our continued research and analysis of early literature and other cultural artifacts continues to show us, is that our modern society, beliefs and practices are more similar to those of medieval and early societies than they are dissimilar, both in positive and negative ways. Such a realization allows us, then, to better examine our own society and perhaps learn from the destructive social and political patterns we recognize as repeating throughout history. Moreover, writers such as Christine de Pizan demonstrate to us that for as long as women and people who identify differently than the established norm have been disadvantaged and oppressed, they have also been fighting for representation and equality. This can be a sobering thought; have we really come no further than fifteenth-century France? Of course we have, but there is still an enormous amount of work to be done to ensure that all identities are treated with compassion and acceptance, and accorded the same - human - rights. This reality has become glaringly obvious under the current administration in the United States. But, the knowledge that even six centuries ago, writers were actively questioning the status quo and reimagining gender roles to any extent is also encouraging and inspiring - it reaffirms our resilience and persistence as human beings.

Of course, the question always remains, are we not simply imposing modern theory and beliefs onto this literature? While I firmly agree that it is imperative that we not force a text to fit a rigid analysis, I do believe that continuing to examine and interpret early literature as our perspectives, comprehension of society, and in this specific case gender identities, evolves and progresses, remains incredibly important. Our opinions of it will necessarily change, our understandings and the ways in which a certain text does 
or does not apply to our current affairs will as well; and I believe this to be a good thing. It means that we are continuing to use literature, historical and cultural artifacts to reflect on the triumphs and imperfections of modern society.

\section{Works Cited}

Adams, Tracy. “État Présent: Christine de Pizan.” French Studies, vol. LXXI, no. 3, 2017, pp. 388-400.

Arden, Heather M. “Christine de Pizan's Ditié de Jehanne d'Arc: History, Feminism, and God's Grace.” Joan of Arc and Spirituality. edited by Ann W. Astell and Bonnie Wheeler, Palgrave MacMillan, New York, 2003, pp. 195-208.

Barr, Alan P. “Christine de Pisan's Ditie de Jehanne d'Arc: A Feminist Exemplum for the Querelle des Femmes." Fifteenth Century Studies, vol. 14, Jan. 1, 1988, pp. 112.

Blumenfeld-Kosinski, Renate. "Christine de Pizan and the Misogynistic Tradition." Romantic Review, vol. 81, no. 3, May 1, 1990, pp. 279-92.

Boccaccio, Giovanni. The Fates of Illustrious Men. Translated and abridged by Louis Brewer Hall, Frederick Ungar Publishing Co., 1965.

Brownlee, Kevin. “Christine de Pizan’s Canonical Authors: The Special Case of Boccaccio.” Comparative Literature Studies, Vol. 32, no. 2, 1995, pp. 244-61.

---. "Christine Transforms Boccaccio: Gendered Authorship in the De mulierbus claris and the Cité des dames." Reconsidering Boccaccio Medieval Contexts and Global Intertexts. edited by Olivia Holmes and Dana E. Stewart. U off Toronto Press, 2018, pp. 246-59. 
---. "Martyrdom and the Female Voice: Saint Christine in the Cité des dames. ”Images of Sainthood in Medieval Europe. edited by Renate Blumenfield-Kosinski and Timea Szell. Cornell U Press, 1991, pp. 115-35.

---. "Structures of Authority in Christine de Pizan's Ditié de Jehanne d'Arc." Discourses of Authority in Medieval and Renaissance Literature. edited by Kevin Brownlee and Walter Stephens. University Press of New England, 1989, pp. 131-50.

Brown-Grant, Rosalind. “'Hee! Quel honneur au feminine sexe!': Female Heroism in Christine de Pizan's Ditie de Jehanne d'Arc." Journal of the Institute of Romance Studies, vol. 5, 1997, pp. 123-33.

Butler, Judith. "Bodily Inscriptions, Performative Subversions." Feminisms Redux: An Anthology of Literary Theory and Criticism. edited by Robyn Warhol-Down and Diane Price Herndl, Rutgers University Press, 2009, pp. 465-76.

Corcos, Christine Alice. "From Agnatic Succession to Absolute Primogeniture: The Shift to Equal Rights of Succession to Thrones and Titles in the Modern European Constitutional Monarchy." Michigan State Law Review, vol. 1587, 2012, pp. 1587-1670.

De Pisan, Christine. Le Ditié de Jehanne d'Arc. edited by Angus J. Kennedy and Kenneth Vary, The Society for the Study of Mediaeval Languages and Literature, Oxford, 1977.

---. Le Livre de la cité des dames. translated by Thérèse Moreau and Éric Hicks, Stock/Moyen Age, 2000. 
Dufresne, Laura Rinaldi. "Women Warriors: A Special Case from the Fifteenth Century: The City of Ladies.” Women's Studies, vol. 23, 1994, pp. 111-31.

Fraioli, Deborah. “The Literary Image of Joan of Arc: Prior Influences.” Speculum, vol. 56, no. 4, Oct. 1981 , pp. 811-30.

Hawkins, Joy. "Seeing the Light? Blindness and Sanctity in Later Medieval England." Studies in Church History, vol. 47, 2011, pp. 148-158.

Houston, Nancy. "The Matrix of War: Mothers and Heroes.” Poetics Today, vol. 6, no. 1/2, The Female Body in Western Culture: Semiotic Perspectives, 1985, pp. 15370.

Kelly, Kathleen Coyne. "Useful Virgins in Medieval Hagiography.” Constructions of Widowhood and Virginity in the Middle Ages. edited by Cindy L. Carlson and Jane Weisl. St. Martin’s Press, 1999, pp. 135-64.

Kristeva, Julia. "Motherhood According to Giovanni Bellini: The Maternal Body." The Portable Kristeva. edited by Kelly Oliver. Columbia University Press, 2002, pp. 303-09.

Malcolmson, Cristina. “Christine de Pizan's City of Ladies in Early Modern England.” Debating Gender in Early, Modern England, 1500-1700. edited by Cristina Malcolmson and Mihoko Suzuki, Palgrave, 2002, pp. 15-36.

Margolis, Nadia. "Elegant Closures: The Use of the Diminutive in Christine de Pizan and Jean de Meun." Reinterpreting Christine de Pizan. edited by Earl Jeffery Richards with Joan Williamson, Nadia Margolis, and Christine Reno. U of Georgia Press, 1992, pp. 111-23. 
McLaughlin, Megan. “The Woman Warrior: Gender, Warfare and Society in Medieval Europe.” Women's Studies, vol. 17, 1990, pp. 193-209.

Nowacka, Keiko. "Reflections on Christine de Pizan's 'Feminism'.” Australian Feminist Studies, vol. 17, no. 37, 2002, pp. 81-97.

Phillips, Kim M. “Attributes.” Medieval Maidens: Young Women and Gender in England. 1270-1540. Manchester University Press, 2003, pp. 23-60.

Quilligan, Maureen. “Allegory and the Textual Body: Female Authority in Christine de Pizan's Livre de la Cité des Dames.” Romantic Review, vol. 79, no. 1, 1988, pp. $222-48$.

---. "Rewriting Tradition: The Authority of Female Subjectivity." The Allegory of Female Authority: Christine de Pizan's Cité des Dames. Cornell U Press, 1991, pp. 69103.

---. "Rewriting the Body: The Politics of Martyrdom." The Allegory of Female Authority: Christine de Pizan's Cité des Dames. Cornell U Press, 1991, pp. 189-245.

---. "The Practice of History." The Allegory of Female Authority: Christine de Pizan's Cité des Dames. Cornell U Press, 1991, pp. 246-83.

Robertson, Elizabeth. "Medieval Views of Women and Female Spirituality in the Ancrene Wisse and Julian of Norwich's Showings," Feminist Approaches to the Body in Medieval Literature. edited by Linda Lomperis and Sarah Stanbury, U of Pennsylvania Press, 1993, pp. 142-67.

Rooks, John. "Chapter Seven: The Boke of the Cyte of Ladyes and its Sixteenth-Century Readership." The Reception of Christine de Pizan from the Fifteenth through the 
Nineteenth Centuries: Visitors to the City. edited by Glenda K. McLeod, The Edwin Mellen Press, 1991, pp. 83-100.

Roux, Simone. Christine de Pizan: Femme de tête, dame de coeur. Biographie Payot, 2006.

Solterer, Helen. "Figures of Female Militancy in Medieval France." Signs, vol. 16, no. 3, 1991, pp. 522-49.

---. "Flaming Words: Verbal Violence and Gender in Premodern Paris.” Romantic Review, vol. 86, no. 2, 1995, pp. 355-78.

Stecopoulos, Eleni \& Karl D. Uitti. “Christine de Pizan's Livre de la Cité des Dames: The Reconstruction of Myth.” Reinterpreting Christine de Pizan. edited by Earl Jeffery Richards with Joan Williamson, Nadia Margolis, and Christine Reno, U of Georgia Press, 1992, pp. 48-62.

Uitti, Karl D. "Women Saints, the Vernacular, and History in Early Medieval France." Images of Sainthood in Medieval Europe. edited by Renate Blumenfield-Kosinski and Timea Szell, Cornell U Press, 1991, pp. 247-67.

Warren, Nancy Bradley. "French Women and English Men: Joan of Arc, Margaret of Anjou, and Christine de Pizan in England, 1445-1540.” Exemplaria, vol. 16, no. 2, 2004, pp. 405-36.

Wittig, Monique. "One is not Born a Woman.” The Straight Mind and Other Essays. Beacon Press, 1992, pp. 9-20. 